\title{
Positive and negative effects of cellular senescence during female reproductive aging and pregnancy
}

\author{
Michael C Velarde ${ }^{1,2}$ and Ramkumar Menon ${ }^{3,4}$ \\ ${ }^{1}$ Institute of Biology, University of the Philippines Diliman, Quezon City, Philippines \\ ${ }^{2}$ Buck Institute for Research on Aging, Novato, California, USA \\ 3Department of Obstetrics and Gynecology, University of Texas Medical Branch at Galveston, \\ Galveston, Texas, USA \\ ${ }^{4}$ Department of Clinical Medicine and Obstetrics and Gynecology, Aarhus University, Aarhus, Denmark
}

Correspondence should be addressed to M C Velarde

Email

mcvelarde@up.edu.ph

\begin{abstract}
Cellular senescence is a phenomenon occurring when cells are no longer able to divide even after treatment with growth stimuli. Because senescent cells are typically associated with aging and age-related diseases, cellular senescence is hypothesized to contribute to the age-related decline in reproductive function. However, some data suggest that senescent cells may also be important for normal physiological functions during pregnancy. Herein, we review the positive and negative effects of cellular senescence on female reproductive aging and pregnancy. We discuss how senescent cells accelerate female reproductive aging by promoting the decline in the number of ovarian follicles and increasing complications during pregnancy. We also describe how cellular senescence plays an important role in placental and fetal development as a beneficial process, ensuring proper homeostasis during pregnancy.
\end{abstract}

\section{Key Words \\ - ovarian \\ - uterine \\ - placental \\ - fetal aging \\ - senescent cells}

\section{Introduction}

Cells have a limited capacity to replicate. Once this limit is reached, cells are no longer able to divide, even after treatment with growth stimuli. This limit is called the Hayflick limit or cellular senescence (Hayflick 1965). Once a significant amount of proliferating cells in a tissue undergoes cellular senescence, that tissue's ability to regenerate becomes reduced (Sousa-Victor et al. 2014). Because lack of regenerative potential is a hallmark of tissue aging, senescent cells are often associated with aging and age-related diseases (Herbig et al. 2006, Baker et al. 2016). Indeed, the number of senescent cells increases with age in multiple tissues (Dimri et al. 1995, Herbig et al. 2006, Ressler et al. 2006, Jeyapalan et al. 2007). Cellular senescence, which is defined as the inability of cells to replicate while remaining viable and functional, should not be confused with organismal and tissue senescence, which are defined as gradual functional deterioration of the whole organism and tissue, respectively. To minimize confusion, we reserve the term 'cellular senescence' to refer to the process in which cells undergo irreversible growth arrest but remain viable, while we use the term 'aging' to refer to deterioration in organisms or tissues due to loss of function.

Excessive cellular stress, such as telomere shortening, oncogenic activation, nuclear DNA damage and mitochondrial dysfunction, can induce cellular senescence in multiple cell types (Allsopp et al. 1992, Di Micco et al. 2006, Kang et al. 2015, Wiley et al. 2016). Hallmarks of cellular senescence include persistent elevated expression of cell cycle inhibitors cyclin

Published by Bioscientifica Ltd 
dependent kinase inhibitor 1A (CDKN1A, also known as p21 WAF1) and CDKN2A (also known as p16 p16 ${ }^{\mathrm{INK} 4 \mathrm{~A}}$, increased activity of a lysosomal enzyme termed senescence-associated $\beta$-galactosidase (SA- $\beta$-gal), presence of nuclear DNA damage foci, presence of senescenceassociated heterochromatin foci (SAHFs), increased cell size, loss of nuclear High Mobility Group Box 1 (HMGB1) and decreased expression of lamin B1 (Dimri et al. 1995, Freund et al. 2012, Davalos et al. 2013). Senescent cells are viable and will survive in culture, as opposed to apoptotic cells, which undergo programmed cell death (Childs et al. 2014). Senescent cells also express several proinflammatory cytokines, growth factors and matrix metalloproteinases, collectively termed senescenceassociated secretory phenotype (SASP) (Coppé et al. 2008). The ability of senescent cells to elicit an SASP is thought to affect tissue homeostasis and promote age-related degenerative diseases and cancers (Laberge et al. 2015, Liu et al. 2015, Xu et al. 2015). This is further supported by a study showing that selectively eliminating senescent cells (using CDKN2A as a marker for cellular senescence) delays the onset of age-related pathologies, such as sarcopenia, cataracts and loss of subdermal adipose tissue in BubR1insufficient mice, a mouse model of premature aging (Baker et al. 2011).

Cellular senescence, particularly that caused by telomere attrition, is hypothesized to contribute to the decline in reproductive function with age. Moreover, senescent cells are associated with pregnancy complications, such as preterm births. However, cellular senescence is also implicated in maintaining proper homeostasis during pregnancy, human parturition (Behnia et al. 2015) and fetal development (MuñozEspín et al. 2013, Storer et al. 2013), suggesting that senescent cells are beneficial during early development. Here, we present evidences that senescent cells can have positive and negative effects in female reproduction and aging, depending on context. This supports a role for antagonistic pleiotropy in cellular senescence.

\section{Cellular senescence and ovarian aging}

Ovarian aging is the process of gradual deterioration in ovaries' ability to generate gametes capable of producing healthy, viable offspring. Ovarian aging involves continuous loss of ovarian follicles until the total number of follicles falls to an amount that results in subsequent progressive decline in female fertility. As a consequence, ovarian aging also leads to a decrease in ovaries' ability to produce enough sex steroid hormones necessary for normal physiological functions in female adults (Richardson et al. 1987). This decline occurs because ovarian follicular cells (granulosa and theca cells) are important sources of sex steroid hormones in women (Tureck \& Strauss 1982, Voutilainen et al. 1986). Hence, the continuous drop in the number of follicles with age results in hormone imbalance and ovarian cycle irregularity. During perimenopause, the deteriorating amount of ovarian follicles gives rise to decreased progesterone secretion, increased estrogen production and a higher estrogen-to-progesterone ratio (Santoro et al. 1996, Finch 2014). During menopause, the significant loss of ovarian follicles ultimately leads to reduced levels of estrogen and progesterone production, followed by the appearance of age-related health problems, such as bone loss and hot flashes (Gold et al. 2006, Finkelstein et al. 2008, Bromberger et al. 2010). Moreover, aged ovaries may also contain more poor-quality oocytes, resulting in embryos that undergo developmental arrest, develop aneuploidy, fail to implant and result in miscarriages (Romeu et al. 1987, Navot et al. 1991, Templeton et al. 1996, Nybo Andersen et al. 2000, Steuerwald et al. 2001, Pellestor et al. 2003). Poor oocyte quality with advanced age is also observed in rodents (Parkening \& Soderwall 1974, 1975, Fujino et al. 1996, Simsek-Duran et al. 2013).

While the ovaries are considered aged by the time a woman reaches menopause at an average age of 51, the gradual deterioration process in ovarian function during aging is thought to begin early in life because the number of ovarian follicles starts to gradually decline prenatally and is not readily replaced (Wallace \& Kelsey 2010), although there is a debate regarding the existence of active germ stem cells in postnatal human ovaries (White et al. 2012, Zhang et al. 2015). Nonetheless, ovarian follicles become significantly depleted with age due to continuous differentiation (i.e. maturation and ovulation) and apoptosis (i.e. follicular atresia) (McGee \& Hsueh 2000). As a result, fertility in women progressively declines with age until women are no longer able to produce oocytes capable of fertilization. This decline in fertility occurs well before menopause (Dunson et al. 2004). Hence, it is believed that the size of the initial ovarian follicle reserves contributes to reproductive lifespan and the onset of hormone-dependent age-related diseases in women.

The role of senescent cells on aging of different tissues implicates that these cells may also promote premature aging of the ovaries. While direct evidence of this contribution to the female reproductive lifespan is limited, several studies on telomerase activity and

Published by Bioscientifica Ltd 
telomere length suggest that shortened telomeres, which can lead to replicative senescence, impair female reproduction. Indeed, oocytes from women who did not conceive vs those who conceived after in vitro fertilization show reduced telomere length (Keefe et al. 2007). Oocytes with shortened telomeres also produced fragmented embryos after fertilization (Keefe et al. 2005). In mice, telomerase deficiency decreases eggs' ability to fertilize with wild-type sperm, reduces fertilized eggs' ability to progress through the blastocyst stage and increases the incidence of fetal deaths, even though ovaries in telomerase-deficient mice can still produce follicles at different stages of follicular development (Lee et al. 1998, Liu et al. 2004). Because unfertilized oocytes (such as in humans and mice) have low telomerase activity (Wright et al. 1996, Liu et al. 2007), oocytes may be susceptible to telomere shortening and cellular senescence during aging.

Excessive DNA double-strand breaks cause cells to undergo cellular senescence and/or apoptosis (d'Adda di Fagagna et al. 2003, Konishi et al. 2003). While the mechanism that determines how a cell is programmed to undergo cellular senescence versus apoptosis is not fully understood, it is evident that specific conditions will preferentially induce cellular senescence over apoptosis. For example, low dose of the DNA-damaging agent doxorubicin leads to cellular senescence, while high dose will induce apoptosis in rat cardiomyocytes (Spallarossa et al. 2009, Altieri et al. 2012). Low dose of $\mathrm{H}_{2} \mathrm{O}_{2}$ also induces cellular senescence in human lung and skin fibroblasts, while high dose promotes apoptosis in these cells (Chen \& Ames 1994, Chen et al. 2000). Some DNAdamaging agents, such as busulfan, preferentially cause human lung fibroblasts to undergo cellular senescence instead of apoptosis (Probin et al. 2006).

As opposed to apoptosis, cellular senescence allows cells to survive in culture, even in the presence of unrepaired DNA double-strand breaks (Chaturvedi et al. 1999, Marcotte et al. 2004, Sedelnikova et al. 2004). Formation of DNA double-strand breaks is part of meiotic recombination during oocyte development, but these DNA strand breaks are readily repaired by DNA repair machineries (Pittman et al. 1998, Baudat et al. 2000, 2013, Mahadevaiah et al. 2001, Di Giacomo et al. 2005). In both humans and mice, expression of DNA double-strand break repair genes, such as Breast Cancer 1 (BRCA1), Meiotic Recombination 11 (MRE11), RAD51 recombinase (RAD51) and ataxia-telangiectasia mutated $(A T M)$, decreases with age in oocytes and is accompanied by increasing DNA double-strand breaks (Titus et al. 2013). The role of DNA damage repair during oocyte development is further demonstrated using wild-type and knockout mouse models. In the presence of excessive DNA double-strand breaks, oocytes undergo prolonged growth arrest (meiotic arrest) in culture, partly due to sustained activation of spindle assembly checkpoint (Lin et al. 2014, Collins et al. 2015). Impaired DNA double-strand break repair, such as that observed in oocytes with deficiencies in BRCA1, MRE11, RAD51 and $A T M$, limits the number of mouse oocytes from progressing through meiosis I and prevents oocytes from maturing (Barlow et al. 1998, Titus et al. 2013).

Another potential mechanism whereby cellular senescence can accelerate ovarian aging is by limiting the proliferation of primordial germ cells (PGCs). Oocytes arise from PGCs that later develop into primordial follicles, which represent the initial ovarian reserve (Witschi 1948, Grive \& Freiman 2015). Hence, cellular senescence in PGCs may result in a significant reduction in the number of primordial follicles formed during fetal development (Fig. 1). However, while this idea seems plausible, the impact of cellular senescence in establishing the initial ovarian reserve is still unknown. Furthermore, it is still unclear whether PGCs can undergo permanent cell cycle arrest because PGCs can transform into pluripotent embryonic germ (EG) cells and continue to proliferate in culture depending on the condition (Matsui et al. 1992, Koshimizu et al. 1996). Hence, future experiments are still needed to test whether cellular senescence in PGCs has an in vivo impact in limiting the size of the initial ovarian follicle reserve, resulting in reduced female reproductive lifespan.

While the role of replicative senescence in limiting germ cell numbers remains unclear, the impact of replicative senescence in promoting growth arrest of somatic cells is more evident. Cellular senescence is already observed in several types of somatic cells (Dimri et al. 1995, Noureddine et al. 2011, Bhat et al. 2012, Wu et al. 2013, Velarde et al. 2012, 2015, Demaria et al. 2014). Hence, it is highly likely for ovarian somatic cells (granulosa and theca cells) to also undergo cellular senescence. Short telomeres and low telomerase activity in granulosa cells are observed in women ( $\leq 37$ years old) with diminished ovarian reserve (Butts et al. 2009). In humans, shortened telomere length in cumulus cells, which are specialized granulosa cells, is associated with the development of poor embryos (Cheng et al. 2013). In aged mice, cumulus cells also facilitate apoptosis of the adjacent oocyte they enclose (Perez \& Tilly 1997), partly by transferring ceramide from cumulus cells (Perez et al. 2005). Interestingly, ceramide is also increased in

Published by Bioscientifica Ltd. 


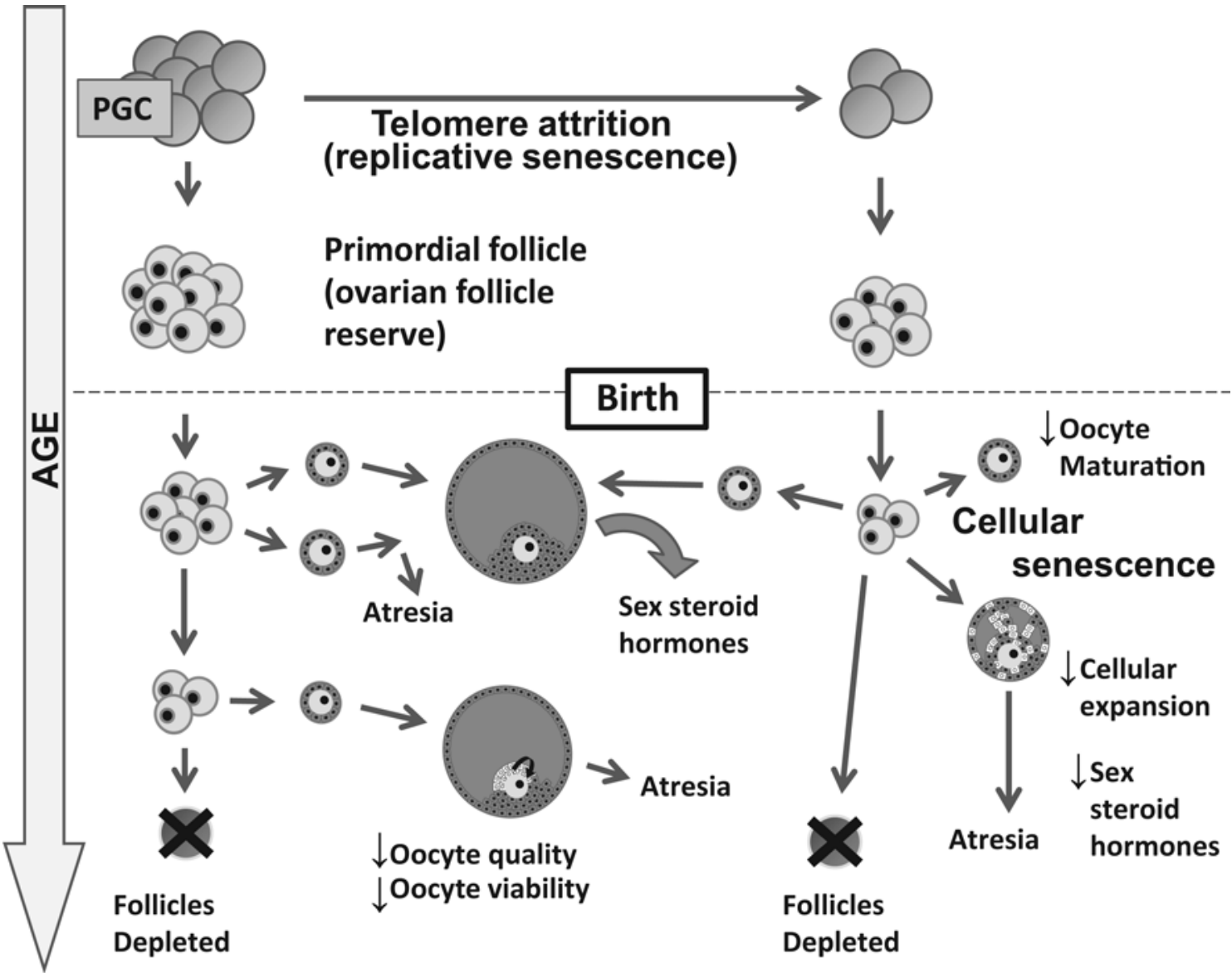

Figure 1

Cellular senescence accelerates the decline in ovarian function. The number of initial primordial germ cells (PGCs) predetermines the size of the initial ovarian follicle reserve. Some of these primordial follicles further develop, but only one becomes dominant (in humans), while the remaining follicles undergo atresia. Maturation of the follicles ensures sufficient production of sex steroid hormones with each menstrual cycle. With age, oocyte quality and viability decrease partly due to impaired signaling in the oocytes and/or support cells. For example, cumulus cells may facilitate apoptosis of the oocyte that they enclose, as depicted by a small black arrow. The total number of ovarian follicles eventually becomes depleted, causing a woman to become infertile. Telomere attrition in PGCs, which leads to replicative senescence, reduces the size of the initial follicle reserve, resulting in a faster decline in ovarian follicle numbers and sex steroid hormone production. Cellular senescence in oocytes inhibits meiotic progression and oocyte maturation. Cellular senescence in support cells limits cellular expansion in these cells, causing failure in the ability of the growing follicles (including the dominant follicle) to fully mature. Inhibiting the ability of follicles to reach preovulatory stage will trigger atresia to immature follicles, resulting in decreased fertility per menstrual cycle, which also results in impaired sex steroid hormone production.

senescent fibroblasts (Venable et al. 1995). Ceramide inhibits DNA replication and induces expression of the senescence marker $\beta$-galactosidase (Mouton \& Venable 2000). This suggests that increased ceramide production in cumulus cells during old age may be associated with cellular senescence in these cells.

Support cells surrounding the oocyte play important roles in egg development. During folliculogenesis, one or a few ovarian follicles become dominant and go through ovulation, while others fail to reach preovulatory stage, trigger apoptosis and succumb to atresia (Block 1951, Yuan \& Giudice 1997). Because support cells are important for selecting follicles, which will either become dominant or undergo atresia (Matsuda et al. 2012), lack of proliferation and cellular expansion in support cells due to replicative senescence may suppress the ability of growing follicles to advance to the preovulatory stage, making all of these immature follicles destined for apoptosis instead (Fig. 1). In humans, chemotherapy (doxorubicin), which induces DNA double-strand breaks and cellular senescence in normal cells, also promotes a majority of oocytes (34.7\%) and granulosa cells (12.1\%) to undergo apoptotic death, reminiscent of premature ovarian aging (Soleimani et al. 2011). In other species, such as bovine and rodents, decreased telomerase activity in granulosa cells is associated with an increased

Published by Bioscientifica Ltd. 
rate of apoptosis and follicular atresia (Lavranos et al. 1999, Yamagata et al. 2002). Proteomic analysis of aged vs immature rat primordial follicles also shows decreased expression of proteins associated with DNA repair (Govindaraj \& Rao 2015).

Granulosa and theca cells of the ovarian follicles are also important sources of estrogen and progesterone in female physiology. These cells orchestrate a series of enzymatic processes to produce estrogen and progesterone during the menstrual cycle. Granulosa cells synthesize estrogen through aromatization of theca-derived androgens, while luteinized follicular cells produce increased amounts of progesterone (Tureck \& Strauss 1982, Voutilainen et al. 1986). Permanent growth arrest in granulosa and theca cells may inhibit ovarian follicles' ability to mature; as a result, immature follicles undergo atresia (Fig. 1). If this were to happen, we speculate that ovarian follicles may deplete faster due to continuous ovulation and follicular atresia, which causes the individual to reach menopause at an earlier age. Whether cellular senescence in support cells causes females to manifest distinct perimenopausal symptoms before menopause is not yet known. Nevertheless, an increased number of nondividing senescent follicular cells may lower female reproductive capacity and sex steroid hormone production and negatively impact normal female physiology.

\section{Cellular senescence and uterine aging}

In contrast to the ample evidence of aging's negative effects in the ovaries, the impact of age on uterine function is less clear. Several studies on human embryo transfers show that the age of female recipients does not affect implantation rates (Serhal \& Craft 1989, Navot et al. 1991, Sauer et al. 1992, Abdalla et al. 1997), suggesting that the uterus is able to support pregnancy even at older ages. However, fetal health conditions originating in the perinatal period, particularly stillbirths, are elevated with increasing maternal age (Fretts et al. 1995, Huang et al. 2008, Flenady et al. 2011). This correlation is also evident in mice and rabbits in which there is increased embryo mortality when blastocysts are transferred from young animals to the uteri of older recipients (Maurer \& Foote 1971, Gosden \& Fowler 1979). While the underlying cause for the age-dependent effect on fetal deaths is still unclear, it is hypothesized that impaired decidualization and uterine-embryo crosstalk are partly responsible for the perinatal mortality. Indeed, uteri of aged rodents showed impaired induction of a decidual response relative to uteri of younger animals (Parkening \& Soderwall 1973, Shapiro \& Talbert 1974, Holinka \& Finch 1977, Ohta 1987).

In addition to impaired decidualization, intrapartum complications, such as long duration of labor and elevated risk of operative vaginal birth and emergency Cesarean deliveries, also increase with age (Smith et al. 2008), which suggests that parturition is significantly compromised at older ages. Because the myometrium plays a direct role in uterine contractions, myometrial function may also be impaired with age. Indeed, myometrium from older women have reduced spontaneous activity and increased likelihood of multiphasic spontaneous myometrial contractions relative to younger women (Smith et al. 2008).

Senescent cells are observed in the uterus. A study on uterine fibroids reports that tissues from older patients ( $\geq 45$ years old) have increased cellular senescence relative to those from younger patients ( $<45$ years old) (Laser et al. 2010). In mice, aged uteri are associated with the downregulation of several genes related to cell proliferation and stem cell renewal (Simmen et al. 2015), suggesting the presence of cells with impaired proliferation during uterine aging. The impact of cellular senescence on uterine function is further implied from studies on telomerase activity. In telomerase RNA (mTR) null mice, telomerase deficiency in the uterus impairs its ability to support wild-type embryos up to full term (Lee et al. 1998). These mice have reduced myometrial thickness, atrophic smooth muscle cells and slight reduction in uterine size (Lee et al. 1998). Hence, the presence of shortened telomeres, presumably leading to cellular senescence, may negatively affect uterine environment conducive for successful pregnancy.

Cellular senescence in the uterus is thought to decrease decidualization response and promote preterm births during pregnancy (Fig. 2). Indeed, cellular senescence in human endometrial stromal cells is accompanied by impaired decidualization as a consequence of inhibiting neddylation (Liao et al. 2015) or suppressing the cAMP mediator, Rap guanine nucleotide exchange factor 3 (RAPGEF3) (Kusama et al. 2014), resulting in a phenotype reminiscent of that observed with advanced age. In mice, persistently high levels of senescent cells in uteri by tissue-specific deletion of the tumor protein p53 (Trp53) gene in progesterone receptor-expressing cells also reduced decidual growth without altering the number of implantation sites (Hirota et al. 2010). Further proteomic analysis on these mice showed downregulated expression of a cluster of antioxidant enzymes in Trp53-deficient decidua (Burnum et al. 2012), 


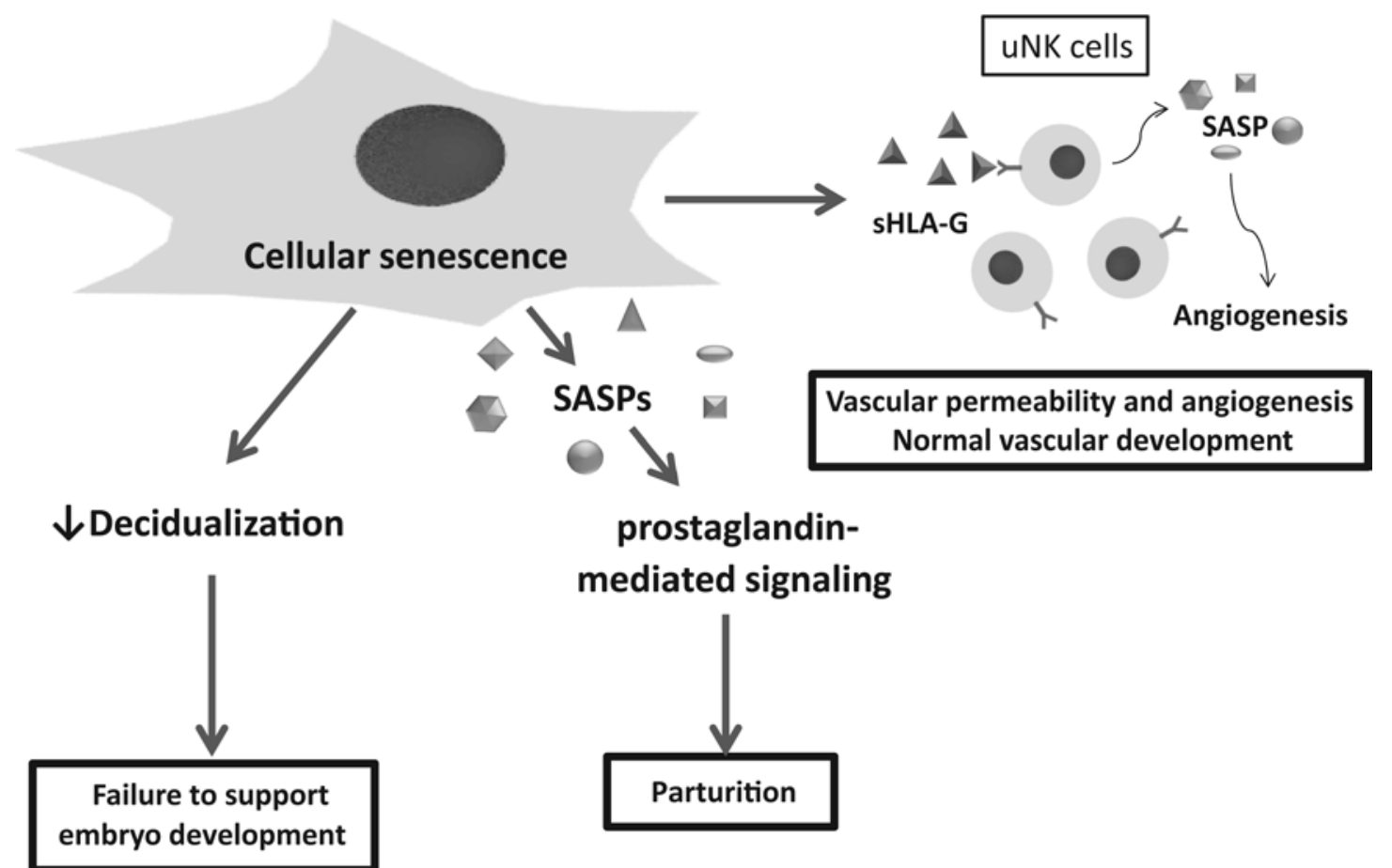

Figure 2

Cellular senescence accelerates the decline in uterine function. Senescent cells have been associated with impaired decidualization, which causes failure of the uterus to support embryo development. Senescent uterine cells also produce SASP, which activates prostaglandin-mediated signaling pathway and promote parturition. Premature activation of this pathway may be detrimental to pregnancy and can cause adverse pregnancy outcomes, such as spontaneous preterm birth and PPROM. In contrast to uterine cells, cellular senescence in uterine NK cells promotes vascular permeability and angiogenesis during pregnancy.

implicating the involvement of oxidative stress with increased presence of senescent cells in the uterus. Moreover, these tissue-specific Trp53-deficient mice have increased the incidence of preterm birth and neonatal deaths, partly due to the activation of a prostaglandinmediated pathway (Hirota et al. 2010). Low doses of rapamycin, an inhibitor of mTORC1 signaling, can prevent preterm birth in these mice (Hirota et al. 2011). mTOR is an important positive regulator of the SASP, and rapamycin can inhibit expression of SASP factors (Laberge et al. 2015). Hence, we speculate that SASP produced by senescent cells in the uterus contributes to preterm birth and neonatal deaths, supporting the involvement of senescent cells in uterine function. However, while senescent cells are implicated in the uterus, the physiological and pathophysiological factors that promote and establish cellular senescence in the uterus during aging remain elusive. For example, it remains unknown whether reduced levels of sex steroid hormones during menopause can also promote cellular senescence in the uterus, in addition to creating a state of quiescence.
In contrast to uterine cells, a surprising beneficial role of senescent cells is found in uterine immune cells during pregnancy (Fig. 2). Natural killer (NK) cells are abundant in the uterus, where they are thought to play important roles for embryo implantation and pregnancy maintenance (Bulmer \& Lash 2015). Several factors, such as soluble HLA-G (sHLA-G), a major histocompatibility complex molecule secreted by fetal trophoblasts during early pregnancy, can activate NK cells (Rajagopalan \& Long 1999, Rajagopalan et al. 2006). Interestingly, sHLA-G, through its receptor KIR2DL4 (CD158d), can induce a DNA damage response, promote cellular senescence and trigger an SASP-like secretion in uterine NK (uNK) cells (Rajagopalan \& Long 2012). This KIR2DL4-induced SASP-like expression in senescent uNK cells is capable of inducing vascular permeability and angiogenesis (Rajagopalan \& Long 2012). Hence, cellular senescence in uNK cells may be a part of normal vascular development, which is necessary in establishing and maintaining healthy pregnancy. On the other hand, it remains unknown whether senescent uNK cells play a role in uterine function during aging.

Published by Bioscientifica Ltd. 


\section{Cellular senescence, placental aging and fetal membrane aging}

Placental weight increases as the age of the mother increases (Haavaldsen et al. 2011). This increase also occurs in rats; the placental weight of older rats (9-12 months) is $40-70 \%$ higher than younger (3-5 months) animals (Rahima \& Bruce 1987). However, whether this age-dependent change in placental size contributes to its function remains unclear. One possible hypothesis is that placental enlargement may compensate for accumulative cellular damage. Consistent with this idea, large placentas with low fetal birthweights are associated with increased risk of various adult-onset diseases, including cardiovascular diseases (Eriksson et al. 2011), suggesting that age-related placental topographic changes may preprogram the fetus for a shorter healthspan during adulthood. Unfortunately, studies on the relationship of age and placental function are limited. Some studies even suggest that age does not influence placental development, as reflected by a similar odds ratio of abnormal placentation in both older ( $>49$ years old) and younger ( $<43$ years old) women who underwent assisted reproductive technology (Kort et al. 2012). Hence, the impact of aging on placental function, as well as the contribution of placenta in aged individuals to adult health span of succeeding progenies, is an important avenue to study.

Another proposed concept is the idea that placentas undergo a transformation process during normal pregnancy, leading to tissue aging and cell death. Placental aging was thought to occur because placentas undergo considerable histological changes throughout normal gestation (Kosanke et al. 1993). Moreover, prolonged pregnancy (beyond 42nd week of gestation) was hypothesized to increase perinatal mortality as a consequence of a placenta reaching its aged state, termed placental insufficiency (Vorherr 1975). Extensive early placental calcification was proposed to be associated with adverse pregnancy outcome and was used as a clinical sign of placental aging (Tindall \& Scott 1965, Hassler 1969). Previously, X-rays were used to identify increased placental calcification, which is associated with the term human pregnancies, corresponding to the accumulation of mineral deposits, especially around the vessels and in the allantois (Tindall \& Scott 1965). In later years, observation of calcification in the basal and chorionic plates by a sonographic placental grading system was postulated as an indirect measurement of placental age and maturity (Grannum et al. 1979). Grannum's placental grading system was extensively used by clinicians to predict complications in high-risk pregnancy (Kazzi et al. 1983, Patterson et al. 1983, Vosmar et al. 1989, Chitlange et al. 1990, McKenna et al. 2005, Chen et al. 2011, 2012). Placental calcification was used to reflect aging, as well as underlying placental dysfunction, especially when it occurred in earlier stages of pregnancy (Chen et al. 2011). However, heterogeneities in diagnosing adverse pregnancy outcomes based on Grannum's criteria created more controversy rather than providing a strategy to detect placental-associated pathologies and adverse pregnancy outcomes. Moreover, there is no evidence that aging causes placental calcification. Hence, placental aging may not be an accurate terminology, because a fullterm placenta does not necessarily have reduced tissue function, impaired homeostasis and decreased tissue repair (Boyd 1984, Jackson et al. 1992). A systematic review (Polettini et al. 2015a) reports that although placental aging has been mentioned in the literature since the early 1970s as a natural physiologic process depicting the life of placenta, there are no reports on mechanistic progression of placental aging, which is partly attributed to impracticality of longitudinal sampling of human placenta. As a result, examinations of placental specimens are always confounded with multiple unknown factors. Hence, the cause-effect relationship is hard to interpret.

Cellular senescence is implicated in normal placental development (Fig. 3). Decreased telomerase activity, which can lead to replicative senescence, seems to be associated with placental maturation (Kyo et al. 1997). Moreover, markers of cellular senescence are observed in human syncytiotrophoblasts after fusion of cytotrophoblasts (Chuprin et al. 2013). After fusion, these senescent cells also secrete SASP components, such as interleukin 6 (IL6), IL8, chemokine C-X-C motif ligand 1 (CXCL1) and chemokine C-C motif ligand 5 (CCL5) (Chuprin et al. 2013). Because senescent cells are irreversibly growth-arrested, induction of cellular senescence in syncytiotrophoblasts is hypothesized to maintain cell cycle arrest and support cell viability in the postmitotic syncytium. However, it is still unclear whether senescent placental cells are overall beneficial or detrimental to pregnancy. One study links telomere shortening and increased cellular senescence in placenta to intrauterine growth restriction (Davy et al. 2009), a condition which increases infant mortality and adult morbidity, such as cardiovascular disease, obesity and diabetes (Hales et al. 1991, Barker et al. 1993, Osmond et al. 1993, McCance et al. 1994, Valdez et al. 1994). Hence, the role of senescent placental cells in maintaining pregnancy needs further

Published by Bioscientifica Ltd. 


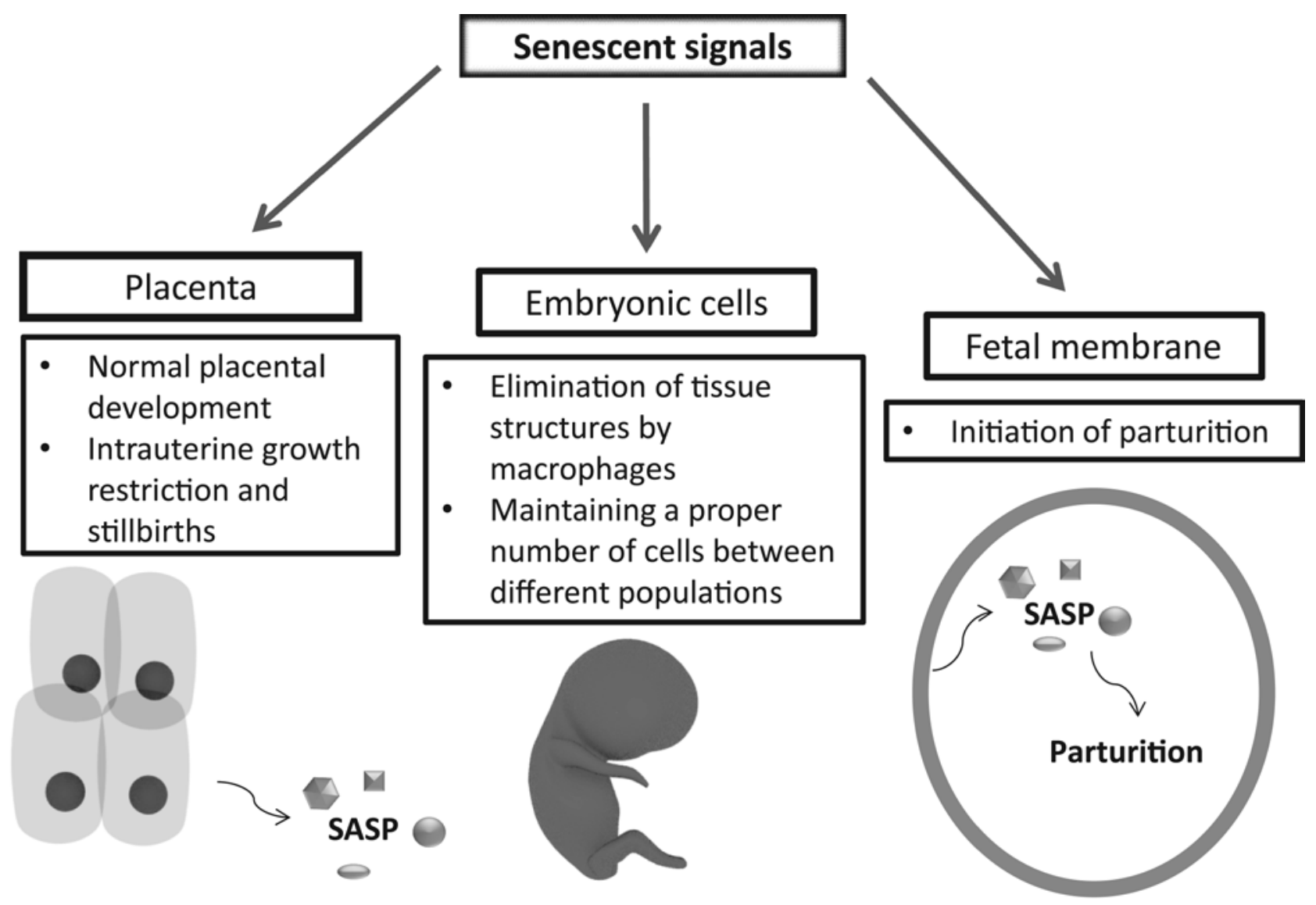

Figure 3

Cellular senescence maintains proper homeostasis during pregnancy by ensuring normal placental, fetal and fetal membrane development. Cellular senescence contributes to the complex interplay of chemical signals during pregnancy. In the placenta, cellular senescence ensures normal placental development, but may also be associated with intrauterine growth restriction and stillbirth. In the embryo, cellular senescence facilitates elimination of tissue structures by macrophages and maintains a proper number of cells between different populations. In the fetal membrane, senescent cells initiate parturition.

investigation. Nonetheless, these reports provide evidence for the presence of senescent cells in the placenta.

The placenta grows along with the fetus throughout pregnancy, especially in the first half, to support growth and development of the fetus. Placental (trophoblast) cells divide and become highly invasive by 12 th week of gestation (Caniggia et al. 2000). During pregnancy, amnion and chorion develop independently until week 14-15, fuse around 15-16 weeks, and form the intrauterine cavity surrounding the fetus. Fetal membranes are an independent entity between the mother and the fetus with unique function that is different than the placenta and should not be considered as an extension of the placenta. They provide unique functions to the growing fetus and for the maintenance of pregnancy. Like placenta, fetal membranes act as mechanical and immune barriers and protect the fetus against infectious agents and noxious environmental insults (Kjaergaard et al. 1999).
Membranes also regulate several endocrine signals (Li \& Challis 2005, Menon et al. 2008, Kumar et al. 2015, Meng et al. 2016). Although fetal membranes and the placenta are both fetal in origin, are attached to one another and develop together with the fetus, placenta and fetal membranes have distinct cellularity and physiology. Placentas are highly vascularized and are the major supply route for the growing fetus, while fetal membranes are avascular and surround the fetus to serve as the main mechanical barrier (Pijnenborg et al. 1980, Meekins et al. 1997, König et al. 2012). The endocrine and uterotonic functions played by placenta and fetal membranes and the biochemical markers that they produce are also distinct (Kacerovsky et al. 2014, Menon et al. 2015). Moreover, while the placenta retains the functional capacity to supply materials to the fetus and ensures fetal survival until it is delivered, fetal membranes are readily ruptured before parturition (El Khwad et al. 2005, 2006, Pandey et al. 2007,

Published by Bioscientifica Ltd 
Strohl et al. 2010). Hence, fetal membranes are anatomically and functionally distinct from placenta.

Telomere length reduction in preterm fetal membranes suggests that preterm birth has similar features to premature aging and age-related pathologies (Menon et al. 2012). Consistent with this idea, cellular senescence in fetal membranes is implicated in pregnancy complications, such as preterm premature rupture of the membranes (pPROM) (Menon et al. 2014a). In relation to pregnancies with preterm birth without rupture of membranes (PTB with no ROM), pPROM pregnancies also have elevated amniotic fluid (AF) inflammatory markers (Athayde et al. 1998, 1999), high salivary collagenolytic activity (a surrogate for lower uterine segment activity) (Menon et al. 2006), elevated AF F2-Isoprostane concentrations (a marker for oxidative stress) (Menon et al. 2011a), shortened fetal leukocyte and placental DNA telomere length (a marker of cellular senescence) (Menon et al. 2012), and distinct single nucleotide polymorphisms (SNPs) associated with common inflammatory pathway genes (Wang et al. 2006, Romero et al. 2010a,b). Hence, cellular senescence in fetal membranes is suggested to promote pregnancy complications. Indeed, increasing the number of senescent cells in fetal membranes, such as those induced by cigarette smoke extract, is thought to cause PTB (Menon et al. 2013).

Human fetal membrane cells are capable of proliferating, but they enter a cellular senescence, growth arrest phase, before normal labor (Behnia et al. 2015). In mouse fetal membranes, senescent cells also progressively increase throughout gestation and peaks at term (Bonney et al. 2016), suggesting that cellular senescence in human and mouse fetal membranes may play a role in initiating parturition (Fig. 3). Oxidative stress peaks at term and is thought to accelerate senescence of human fetal membranes (Menon et al. 2014a). The third trimester of pregnancy is a state of hypoxic environment, but metabolism increases as fetal maturity is completed, enhancing the release of reactive oxygen species (ROS) (Diamant et al. 1980, Many \& Roberts 1997). DNA bases, especially guanine nucleotides, are vulnerable targets for ROS (Kasai \& Nishimura 1986, Kasai et al. 1986). Increased oxidative stress-induced DNA damage, predominated by accumulation of oxidized guanine bases (8-oxoguanine), in fetal membranes causes guanine-rich telomere attrition and activation of cellular senescence (Menon et al. 2014b). This reduction in telomeres and lack of base excision repair of guanine bases are correlated with reduced expression of the base excision repair gene 8-oxoguanine DNA glycosylase (OGG1) in human fetal membranes
(Menon et al. 2014b). Massive influx of oxidative stress before initiation of labor creates irreversible damage to intracellular compartments (Cindrova-Davies et al. 2007, Khan et al. 2010). Oxidative stress-induced damage in fetal membrane cells may promote cellular senescence and SASP secretion. Hence, DNA damage-induced inflammation and SASP factors secreted from senescent fetal membranes are suggested to promote signals of parturition at term (Behnia et al. 2015).

In addition, a gradual decrease in telomere length is also thought to promote the senescent phenotype in fetal membranes, as indicated by morphologic (enlargement of organelles) and biochemical alterations (activation of MAPK14, increase in SA- $\beta$-gal activity and development of the SASP) (Menon et al. 2014a). This decrease in telomere length can be considered as a sign of replicative senescence, eventually resulting in the secretion of SASP factors, which are thought to initiate parturition during normal labor (Behnia et al. 2015). Moreover, telomere mimetics (TTAGGG ${ }_{(2)}$ repeat sequences), which induce cellular senescence in multiple cancer cells (Klungland et al. 1999, Yaar et al. 2007, Sarkar \& Faller 2011, Rankin et al. 2012, Pitman et al. 2013, Puri et al. 2014), can also cause amnion cell oxidative stress, MAPK14 activation and cellular senescence in fetal membranes (Polettini et al. $2015 b$ ). Telomere fragments also increased the expression of SASP factors IL6 and IL8 from amnion epithelial cells, suggesting a mechanism of sterile inflammation in the intrauterine cavity. These results were further supported by in vivo experiments, wherein injection of T-oligos into the uteri of pregnant CD1 mice on day 14 of gestation led to increased oxidative stress in the amniotic sac and placenta, increased MAPK14 activation and SA- $\beta$-gal activity in murine amniotic sac and higher IL8 levels in amniotic fluid compared with saline-treated controls (Polettini et al. 2015b). These data indicate that telomere shortening can promote cellular senescence in fetal membranes and trigger an inflammatory cytokine signature to activate uterotonins and promote parturition at term, which is consistent with the idea that telomere shortening in fetal membranes can act as a biological clock to facilitate proper timing of parturition in humans and mice (Bonney et al. 2016, Menon et al. 2016).

Fetal hypothalamic-pituitary-adrenal (HPA) axis during parturition is well documented, especially in animal models (e.g. sheep). Corticotropin-releasing hormone (CRH) as a biomarker of term and preterm parturition is also reported in humans (Menon et al. 2011b). In animal models, parturition is either fetal-driven (e.g. fetalHPA and other fetal-derived endocrine factors) and/or

Published by Bioscientifica Ltd 
maternal-driven (e.g. maternal-dependent progesterone withdrawal). However, in humans, the exact initiator of parturition is still unclear. Endocrine signals like CRH alone are insufficient to produce changes in myometrium. Hence, we propose that premature telomere shortening in human fetal membranes may also trigger preterm labor or premature rupture of the membranes (Menon et al. 2014a, Dutta et al. 2016), providing an additional mechanism to induce parturition in humans.

\section{Cellular senescence and fetal development}

The presence of senescent cells in normal developing placenta and fetal membranes suggests that cellular senescence has important functions during pregnancy. In mice, the positive contribution of senescent cells is also observed during normal embryogenesis. During embryo development (E9.5-E14.5), senescent cells are temporally present in the mouse endolymphatic sacs near the ear canals, the posterior cranium that corresponds to the closing neural tube, the otic vesicle, the brain vesicles, the fusing sternum midline, the gut endoderm, the apical ectodermal ridge (AER) of the limbs, the bottom of the regressing interdigital webs, the vibrissae area below the eye, the mesonephric tubules and the vertebral osteoblasts and chondroblasts of the cervical region (Muñoz-Espín et al. 2013, Storer et al. 2013). While the function of senescent cells in these fetal tissues remains largely unclear, the importance of senescent cells in the fetus has been implicated in normal embryo development.

During sexual differentiation in females, lack of androgen and Müllerian inhibiting substance results in the regression of the Wolffian duct (mesonephric tubules) and the development of the Müllerian duct, respectively (Behringer et al. 1994, Welsh et al. 2009). In addition, senescent cells in the mesonephric tubules are also thought to play a role in ensuring a properly timed regression of the tubules during fetal development through the clearance of senescent cells by infiltrating macrophages (Muñoz-Espín et al. 2013), which results in a widespread apoptosis as a means to compensate for the delayed tubule regression. However, despite this compensatory mechanism, absence of cellular senescence in mesonephric tubules of Cdkn1a-null mice during female development is associated with the increased incidence of dorsoventral vaginal septum (Muñoz-Espín et al. 2013), a congenital condition where the vagina is divided. This association suggests that delayed involution of the mesonephric tubules may somehow cause improper fusion of the lower parts of the Müllerian ducts with the urogenital sinus, resulting in the formation of vaginal septum. This increased incidence of septate vagina in Cdkn1a-null mice also leads to reduced litter size (Muñoz-Espín et al. 2013).

Aside from regression of mesonephric tubules, senescent cells are also implicated in eliminating interdigital cells of the AER. Senescent cells in AER are associated with increased apoptosis and macrophage infiltration (Storer et al. 2013). Absence of senescent cells in AER by inhibiting phophorylation of ERK or by inhibition of CDKN1A signaling results in patterning defect of the limbs (Storer et al. 2013).

In addition to the role of senescent cells in eliminating tissue structures through a macrophage-mediated process, senescent cells also maintain a proper distribution of cell population during mouse fetal development (Fig. 3). Cellular senescence in the endolymphatic sac is thought to promote growth arrest in the majority of cells present at E14.5 to allow colonization of a small number of pendrin-positive cells (Muñoz-Espín et al. 2013). Absence of cellular senescence triggers apoptosis and macrophage infiltration to correct the imbalance in cell population during mouse fetal development (Muñoz-Espín et al. 2013). Because this mechanism seems to completely compensate for the lack of cellular senescence response, the significance of cellular senescence in endolymphatic sac needs further investigation.

It is important to note that cellular senescence during mouse fetal development is different from senescent fibroblasts induced by DNA damage, repetitive culture, oncogene activation or tumor suppressor activation. Cellular senescence in mouse embryogenesis is dependent on CDKN1A, but this activation is independent of TRP53, because TRP53 expression is low in fetal tissues and Trp53-null mice show similar presence of senescent cells (Muñoz-Espín et al. 2013, Storer et al. 2013). This is in contrast to the requirement of TRP53 in senescent cells of other somatic tissues, including placenta (Chuprin et al. 2013). Senescent cells during mouse fetal development do not have increased DNA damage and do not express high levels of CDKN2A, but instead have increased expression of other cell cycle inhibitors, CDKN1B (also known as p27) and CDKN2B (also known as p15) (Muñoz-Espín et al. 2013, Storer et al. 2013).

While senescent cells during mouse fetal development differ in their gene expression profile compared with the classic view of cellular senescence, these cells still share a set of commonly regulated genes that are involved in TGFB/SMAD, PI3K/FOXO and SASP regulation

Published by Bioscientifica Ltd. 
(Muñoz-Espín et al. 2013, Storer et al. 2013). Activation of TGFB signaling, by upregulating SMAD phosphorylation and $C d k n 1 a$ gene expression, is associated with increased cellular senescence, while inhibition of PI3K and reduced phosphorylation of FOXO1/3, which is a downstream target of PI3K, are correlated with increased cellular senescence in mesonephric tubules and endolymphatic sac during fetal development (Muñoz-Espín et al. 2013). Genes associated in the regulation of cellular senescence and the SASP, such as CCAAT/enhancer-binding protein beta $(C e b p b)$, insulin-like growth factor-binding protein 5 (Igfbp5), wingless-type MMTV integration site family, member 5A (Wnt5a), colony-stimulating factor 1 (Csf1) and $C d 44$, are comparably increased in developmentally senescent AER and oncogene-induced senescent fibroblast (Storer et al. 2013).

The role of cellular senescence in fetal development is observed in mouse models. However, there is still no evidence indicating the existence of senescent cells during human embryogenesis. Studies are needed to determine whether cellular senescence also plays a role in human fetal development or whether this phenomenon is restricted to mice.

\section{Antagonistic pleiotropic roles of senescent cells}

Senescent cells have positive and negative effects on reproduction. They contribute to female reproductive aging by accelerating the decline in ovarian and uterine function. In the ovaries, senescent cells limit the number of ovarian follicle reserves, decrease the proliferation of granulosa and theca cells and diminish the amount of sex steroid hormone production. In the uterus, senescent cells reduce decidual growth and promote preterm labor. However, senescent cells also maintain proper homeostasis during pregnancy by ensuring normal placental and fetal development. In the placenta, senescent cells are present in syncytiotrophoblasts where they are thought to maintain cell cycle arrest and support cell viability in the postmitotic syncytium. In the fetus, senescent cells facilitate in eliminating tissue structures and in limiting overpopulation of specific cell types. Hence, the positive and negative impact of senescent cells on female reproduction depends on context.

The pleiotropic contributions of senescent cells to reproduction and pregnancy seem very contradictory. Why would nature retain cellular senescence if this process is also deleterious to the organism's ability to

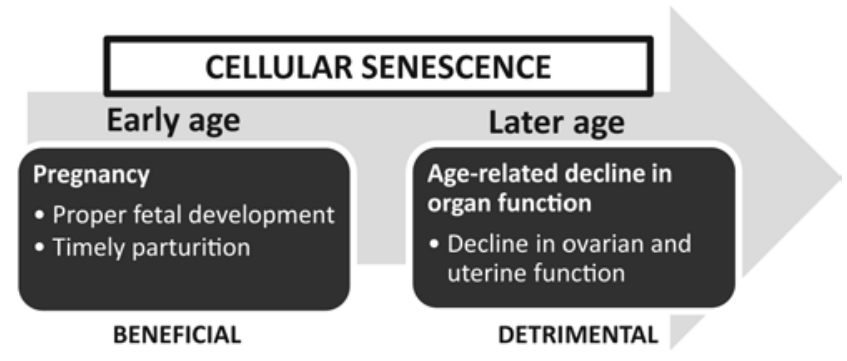

Figure 4

Pleiotropic contributions of senescent cells during aging. Beneficial effects of cellular senescence manifest early in life to facilitate proper fetal development and timely parturition. However, detrimental effects of cellular senescence later in life appear to accelerate the decline in ovarian and uterine function.

reproduce? One possible hypothesis is that the positive effects of senescent cells may outweigh the negative effects. The beneficial roles of senescent cells in ensuring proper homeostasis during pregnancy may be more important than the detrimental effects of these cells on ovarian and uterine aging. Genes controlling the process of cellular senescence may have been selected for during evolution because their positive effects manifest early in life to facilitate proper fetal development and timely parturition, while its negative effects only become apparent later in life when the function of the ovaries and the uterus begins to decline (Fig. 4). This is consistent with the concept of antagonistic pleiotropy theory of aging, originally proposed by George Williams (1957). This theory stipulates that one gene can be both beneficial and detrimental to an organism's fitness, and that this fitness tradeoff is overall beneficial for the species' survival. Current data on senescent cells suggest that antagonistic pleiotropy may also apply to genes involved in cellular senescence. Further investigations on the effects of cellular senescence on female reproductive aging and pregnancy can help address this hypothesis.

\section{Conclusion}

Cellular senescence may be both beneficial and detrimental to reproduction. On one hand, cellular senescence contributes to the progressive decline in female reproductive capacity by promoting a decrease in the number of ovarian follicles and increasing complications during pregnancy. On the other hand, cellular senescence may be important for proper homeostasis during pregnancy by regulating normal placental and

Published by Bioscientifica Ltd. 
fetal development. The pleiotropic contribution of senescent cells to female reproductive function and life span implicates the importance of understanding the complexity of cellular senescence in specific context of reproduction. It will be helpful to further investigate the impact of senescent cells on reproduction using mouse models that allow specific elimination of senescent cells in vivo (Baker et al. 2011, Demaria et al. 2014).

\section{Declaration of interest}

The authors declare that there is no conflict of interest that could be perceived as prejudicing the impartiality of this review.

\section{Funding}

This research did not receive any specific grant from any funding agency in the public, commercial or not-for-profit sector.

\section{Author contribution statement}

$\mathrm{R} \mathrm{M}$ and $\mathrm{M} \mathrm{C} \mathrm{V} \mathrm{wrote} \mathrm{the} \mathrm{review.}$

\section{Acknowledgements}

The authors thank Goldie Tabor and LeAnne Garcia, UTMB Grants and Media Division of OB-Gyn Department for assisting in the proofreading of the manuscript, and Lorenz Rhuel P Ragasa for providing technical support in constructing the figures.

\section{References}

Abdalla HI, Wren ME, Thomas A \& Korea L 1997 Age of the uterus does not affect pregnancy or implantation rates; a study of egg donation in women of different ages sharing oocytes from the same donor. Human Reproduction 12 827-829. (doi:10.1093/humrep/12.4.827)

Allsopp RC, Vaziri H, Patterson C, Goldstein S, Younglai EV, Futcher AB, Greider CW \& Harley CB 1992 Telomere length predicts replicative capacity of human fibroblasts. PNAS 89 10114-10118. (doi:10.1073/ pnas.89.21.10114)

Altieri P, Spallarossa P, Barisione C, Garibaldi S, Garuti A, Fabbi P, Ghigliotti G \& Brunelli C 2012 Inhibition of doxorubicin-induced senescence by PPAR $\delta$ activation agonists in cardiac muscle cells: cooperation between PPAR $\delta$ and Bcl6. PLoS ONE 7 e46126. (doi:10.1371/journal.pone.0046126)

Athayde N, Edwin SS, Romero R, Gomez R, Maymon E, Pacora P \& Menon R 1998 A role for matrix metalloproteinase-9 in spontaneous rupture of the fetal membranes. American Journal of Obstetrics and Gynecology 179 1248-1253. (doi:10.1016/S0002-9378(98)70141-3)

Athayde N, Romero R, Gomez R, Maymon E, Pacora P, Mazor M, Yoon BH, Fortunato S, Menon R, Ghezzi F, et al. 1999 Matrix metalloproteinases-9 in preterm and term human parturition. Journal of Maternal-Fetal Medicine 8 213-219. (doi:10.3109/14767059909052049)
Barker DJ, Osmond C, Simmonds SJ \& Wield GA 1993 The relation of small head circumference and thinness at birth to death from cardiovascular disease in adult life. British Medical Journal 306 422-426. (doi:10.1136/bmj.306.6875.422)

Baker DJ, Wijshake T, Tchkonia T, LeBrasseur NK, Childs BG, van de Sluis B, Kirkland JL \& van Deursen JM 2011 Clearance of p16Ink4a-positive senescent cells delays ageing-associated disorders. Nature 479 232-236. (doi:10.1038/nature10600)

Baker DJ, Childs BG, Durik M, Wijers ME, Sieben CJ, Zhong J, Saltness RA, Jeganathan KB, Verzosa GC, Pezeshki A, et al. 2016 Naturally occurring p16(Ink4a)-positive cells shorten healthy lifespan. Nature 530 184-189. (doi:10.1038/nature16932)

Barlow C, Liyanage M, Moens PB, Tarsounas M, Nagashima K, Brown K, Rottinghaus S, Jackson SP, Tagle D, Ried T, et al. 1998 Atm deficiency results in severe meiotic disruption as early as leptonema of prophase I. Development 125 4007-4017.

Baudat F, Manova K, Yuen JP, Jasin M \& Keeney S 2000 Chromosome synapsis defects and sexually dimorphic meiotic progression in mice lacking Spo11. Molecular Cell 6 989-998. (doi:10.1016/ S1097-2765(00)00098-8)

Baudat F, Imai Y \& de Massy B 2013 Meiotic recombination in mammals: localization and regulation. Nature Reviews Genetics 14 794-806. (doi:10.1038/nrg3573)

Behnia F, Taylor BD, Woodson M, Kacerovsky M, Hawkins H, Fortunato SJ, Saade GR \& Menon R 2015 Chorioamniotic membrane senescence: a signal for parturition? American Journal of Obstetrics and Gynecology 213 359.e1-359.e16. (doi:10.1016/j.ajog.2015.05.041)

Behringer RR, Finegold MJ \& Cate RL 1994 Müllerian-inhibiting substance function during mammalian sexual development. Cell 79 415-425. (doi:10.1016/0092-8674(94)90251-8)

Bhat R, Crowe EP, Bitto A, Moh M, Katsetos CD, Garcia FU, Johnson FB, Trojanowski JQ, Sell C \& Torres C 2012 Astrocyte senescence as a component of Alzheimer's disease. PLoS ONE 7 e45069. (doi:10.1371/ journal.pone.0045069)

Block E 1951 Quantitative morphological investigations of the follicular system in women; variations in the different phases of the sexual cycle. Acta Endocrinologica 8 33-54. (doi:10.1530/acta.0.0080033)

Bonney EA, Krebs K, Saade G, Kechichian T, Trivedi J, Huaizhi Y \& Menon R 2016 Differential senescence in feto-maternal tissues during mouse pregnancy. Placenta 43 26-34. (doi:10.1016/ j.placenta.2016.04.018)

Boyd PA 1984 Quantitative structure of the normal human placenta from 10 weeks of gestation to term. Early Human Development 9 297-307. (doi:10.1016/0378-3782(84)90074-4)

Bromberger JT, Schott LL, Kravitz HM, Sowers M, Avis NE, Gold EB, Randolph JF Jr \& Matthews KA 2010 Longitudinal change in reproductive hormones and depressive symptoms across the menopausal transition: results from the Study of Women's Health Across the Nation (SWAN). Archives of General Psychiatry 67 598-607. (doi:10.1001/archgenpsychiatry.2010.55)

Bulmer JN \& Lash GE 2015 The role of uterine NK cells in normal reproduction and reproductive disorders. Advances in Experimental Medicine and Biology 868 95-126. (doi:10.1007/978-3-319-18881-2)

Burnum KE, Hirota Y, Baker ES, Yoshie M, Ibrahim YM, Monroe ME, Anderson GA, Smith RD, Daikoku T \& Dey SK 2012 Uterine deletion of Trp53 compromises antioxidant responses in the mouse decidua. Endocrinology 153 4568-4579. (doi:10.1210/en.2012-1335)

Butts S, Riethman H, Ratcliffe S, Shaunik A, Coutifaris C \& Barnhart K 2009 Correlation of telomere length and telomerase activity with occult ovarian insufficiency. Journal of Clinical Endocrinology and Metabolism 94 4835-4843. (doi:10.1210/jc.2008-2269)

Caniggia I, Winter J, Lye SJ \& Post M 2000 Oxygen and placental development during the first trimester: implications for the pathophysiology of pre-eclampsia. Placenta 21 S25-S30. (doi:10.1053/plac.1999.0522) http://joe.endocrinology-journals.org

DOI: $10.1530 / J O E-16-0018$
() 2016 Society for Endocrinology Printed in Great Britain 
Chaturvedi V, Qin JZ, Denning MF, Choubey D, Diaz MO \& Nickoloff BJ 1999 Apoptosis in proliferating, senescent, and immortalized keratinocytes. Journal of Bioloical Chemistry 274 23358-23367. (doi:10.1074/jbc.274.33.23358)

Chen Q \& Ames BN 1994 Senescence-like growth arrest induced by hydrogen peroxide in human diploid fibroblast F65 cells. PNAS 91 4130-4134. (doi:10.1073/pnas.91.10.4130)

Chen QM, Liu J \& Merrett JB 2000 Apoptosis or senescence-like growth arrest: influence of cell-cycle position, p53, p21 and bax in $\mathrm{H} 2 \mathrm{O} 2$ response of normal human fibroblasts. Biochemical Journal 347 543-551. (doi:10.1042/0264-6021:3470543)

Chen KH, Chen LR \& Lee YH 2011 Exploring the relationship between preterm placental calcification and adverse maternal and fetal outcome. Ultrasound in Obstetrics and Gynecology 37 328-334. (doi:10.1002/uog.7733)

Chen KH, Chen LR \& Lee YH 2012 The role of preterm placental calcification in high-risk pregnancy as a predictor of poor uteroplacental blood flow and adverse pregnancy outcome. Ultrasound in Medicine and Biology 38 1011-1018. (doi:10.1016/ j.ultrasmedbio.2012.02.004)

Cheng EH, Chen SU, Lee TH, Pai YP, Huang LS, Huang CC \& Lee MS 2013 Evaluation of telomere length in cumulus cells as a potential biomarker of oocyte and embryo quality. Human Reproduction $\mathbf{2 8}$ 929-936. (doi:10.1093/humrep/det004)

Childs BG, Baker DJ, Kirkland JL, Campisi J \& van Deursen JM 2014 Senescence and apoptosis: dueling or complementary cell fates? EMBO Reports 15 1139-1153. (doi:10.15252/embr.201439245)

Chitlange S, Hazari K, Joshi J, Shah R \& Mehta A 1990 Ultrasonographically observed preterm grade III placenta and perinatal outcome. International Journal of Gynaecology and Obstetrics 31 325-328. (doi:10.1016/0020-7292(90)90909-5)

Chuprin A, Gal H, Biron-Shental T, Biran A, Amiel A, Rozenblatt S \& Krizhanovsky V 2013 Cell fusion induced by ERVWE1 or measles virus causes cellular senescence. Genes and Development 27 2356-2366. (doi:10.1101/gad.227512.113)

Cindrova-Davies T, Yung HW, Johns J, Spasic-Boskovic O, Korolchuk S, Jauniaux E, Burton GJ \& Charnock-Jones DS 2007 Oxidative stress, gene expression, and protein changes induced in the human placenta during labor. American Journal of Pathology 171 1168-1179. (doi:10.2353/ajpath.2007.070528)

Collins JK, Lane SI, Merriman JA \& Jones KT 2015 DNA damage induces a meiotic arrest in mouse oocytes mediated by the spindle assembly checkpoint. Nature Communications 6 8553. (doi:10.1038/ncomms9553)

Coppé JP, Patil CK, Rodier F, Sun Y, Muñoz DP, Goldstein J, Nelson PS, Desprez PY \& Campisi J 2008 Senescence-associated secretory phenotypes reveal cell-nonautonomous functions of oncogenic RAS and the p53 tumor suppressor. PLoS Biology 6 2853-2868. (doi:10.1371/journal.pbio.0060301)

d'Adda di Fagagna F, Reaper PM, Clay-Farrace L, Fiegler H, Carr P, Von Zglinicki T, Saretzki G, Carter NP \& Jackson SP 2003 A DNA damage checkpoint response in telomere-initiated senescence. Nature 426 194-198. (doi:10.1038/nature02118)

Davalos AR, Kawahara M, Malhotra GK, Schaum N, Huang J, Ved U, Beausejour CM, Coppe J-P, Rodier F \& Campisi J 2013 p53-dependent release of Alarmin HMGB1 is a central mediator of senescent phenotypes. Journal of Cell Biology 201 613-629. (doi:10.1083/ jcb.201206006)

Davy P, Nagata M, Bullard P, Fogelson NS \& Allsopp R 2009 Fetal growth restriction is associated with accelerated telomere shortening and increased expression of cell senescence markers in the placenta. Placenta 30 539-542. (doi:10.1016/j.placenta.2009.03.005)

Demaria M, Ohtani N, Youssef SA, Rodier F, Toussaint W, Mitchell JR, Laberge RM, Vijg J, Van Steeg H, Dollé ME, et al. 2014 An essential role for senescent cells in optimal wound healing through secretion of PDGF-AA. Developmental Cell 31 722-733. (doi:10.1016/ j.devcel.2014.11.012)
Di Giacomo M, Barchi M, Baudat F, Edelmann W, Keeney S \& Jasin M 2005 Distinct DNA-damage-dependent and -independent responses drive the loss of oocytes in recombination-defective mouse mutants. PNAS 102 737-742. (doi:10.1073/pnas.0406212102)

Di Micco R, Fumagalli M, Cicalese A, Piccinin S, Gasparini P, Luise C, Schurra C, Garre' M, Nuciforo PG, Bensimon A, et al. 2006 Oncogeneinduced senescence is a DNA damage response triggered by DNA hyper-replication. Nature 444 638-642. (doi:10.1038/nature05327)

Diamant S, Kissilevitz R \& Diamant Y 1980 Lipid peroxidation system in human placental tissue: general properties and the influence of gestational age. Biology of Reproduction 23 776-781. (doi:10.1095/ biolreprod23.4.776)

Dimri GP, Lee X, Basile G, Acosta M, Scott G, Roskelley C, Medrano EE, Linskens M, Rubelj I, Pereira-Smith O, et al. 1995 A biomarker that identifies senescent human cells in culture and in aging skin in vivo. PNAS 92 9363-9367. (doi:10.1073/pnas.92.20.9363)

Dunson DB, Baird DD \& Colombo B 2004 Increased infertility with age in men and women. Obstetrics and Gynecology 103 51-56. (doi:10.1097/01.AOG.0000100153.24061.45)

Dutta EH, Behnia F, Boldogh I, Saade GR, Taylor BD, Kacerovský M \& Menon R 2016 Oxidative stress damage-associated molecular signaling pathways differentiate spontaneous preterm birth and preterm premature rupture of the membranes. Molecular Human Reproduction 22 143-157. (doi:10.1093/molehr/gav074)

El Khwad M, Stetzer B, Moore RM, Kumar D, Mercer B, Arikat S, Redline RW, Mansour JM \& Moore JJ 2005 Term human fetal membranes have a weak zone overlying the lower uterine pole and cervix before onset of labor. Biology of Reproduction 72 720-726. (doi:10.1095/biolreprod.104.033647)

El Khwad M, Pandey V, Stetzer B, Mercer BM, Kumar D, Moore RM, Fox J, Redline RW, Mansour JM \& Moore JJ 2006 Fetal membranes from term vaginal deliveries have a zone of weakness exhibiting characteristics of apoptosis and remodeling. Journal of the Society for Gynecologic Investigation 13 191-195. (doi:10.1016/j.jsgi.2005.12.010)

Eriksson JG, Kajantie E, Thornburg KL, Osmond C \& Barker DJ 2011 Mother's body size and placental size predict coronary heart disease in men. European Heart Journal 32 2297-2303. (doi:10.1093/ eurheartj/ehr147)

Finch CE 2014 The menopause and aging, a comparative perspective. Journal of Steroid Biochemistry and Molecular Biology 142 132-141. (doi:10.1016/j.jsbmb.2013.03.010)

Finkelstein JS, Brockwell SE, Mehta V, Greendale GA, Sowers MR, Ettinger B, Lo JC, Johnston JM, Cauley JA, Danielson ME, et al. 2008 Bone mineral density changes during the menopause transition in a multiethnic cohort of women. Journal of Clinical Endocrinology and Metabolism 93 861-868. (doi:10.1210/jc.2007-1876)

Flenady V, Koopmans L, Middleton P, Frøen JF, Smith GC, Gibbons K, Coory M, Gordon A, Ellwood D, McIntyre HD, et al. 2011 Major risk factors for stillbirth in high-income countries: a systematic review and meta-analysis. Lancet 377 1331-1340. (doi:10.1016/ S0140-6736(10)62233-7)

Fretts RC, Schmittdiel J, McLean FH, Usher RH \& Goldman MB 1995 Increased maternal age and the risk of fetal death. New England Journal of Medicine 333 953-957. (doi:10.1056/ NEJM199510123331501)

Freund A, Laberge R-M, Demaria M \& Campisi J 2012 Lamin B1 loss is a senescence-associated biomarker. Molecular Biology of the Cell 23 2066-2075. (doi:10.1091/mbc.E11-10-0884)

Fujino Y, Ozaki K, Yamamasu S, Ito F, Matsuoka I, Hayashi E, Nakamura H, Ogita S, Sato E \& Inoue M 1996 DNA fragmentation of oocytes in aged mice. Human Reproduction 11 1480-1483. (doi:10.1093/oxfordjournals.humrep.a019421)

Gold EB, Colvin A, Avis N, Bromberger J, Greendale GA, Powell L, Sternfeld B \& Matthews K 2006 Longitudinal analysis of the association between vasomotor symptoms and race/ethnicity across the menopausal transition: study of women's health across the 
nation. American Journal of Public Health 96 1226-1235. (doi:10.2105/ AJPH.2005.066936)

Gosden RG \& Fowler RE 1979 Corpus luteum function in ageing inbred mice. Experientia 35 128-130. (doi:10.1007/BF01917920)

Govindaraj V \& Rao AJ 2015 Comparative proteomic analysis of primordial follicles from ovaries of immature and aged rats. Systems Biology in Reproductive Medicine 61 367-375. (doi:10.3109/19396368. 2015.1077903)

Grannum PA, Berkowitz RL \& Hobbins JC 1979 The ultrasonic changes in the maturing placenta and their relation to fetal pulmonic maturity. American Journal of Obstetrics and Gynecology 133 915-922. (doi:10.1016/0002-9378(79)90312-0)

Grive KJ \& Freiman RN 2015 The developmental origins of the mammalian ovarian reserve. Development 142 2554-2563. (doi:10.1242/dev.125211)

Haavaldsen C, Samuelsen SO \& Eskild A 2011 The association of maternal age with placental weight: a population-based study of 536,954 pregnancies. BJOG 118 1470-1476. (doi:10.1111/j.14710528.2011.03053.x)

Hales CN, Barker DJ, Clark PM, Cox LJ, Fall C, Osmond C \& Winter PD 1991 Fetal and infant growth and impaired glucose tolerance at age 64. British Medical Journal 303 1019-1022. (doi:10.1136/ bmj.303.6809.1019)

Hassler O 1969 Placental calcifications. A biophysical and histologic study. American Journal of Obstetrics and Gynecology 103 348-353. (doi:10.1016/0002-9378(69)90493-1)

Hayflick L 1965 The limited in vitro lifetime of human diploid cell strains. Experimental Cell Research 37 614-636. (doi:10.1016/ 0014-4827(65)90211-9)

Herbig U, Ferreira M, Condel L, Carey D \& Sedivy JM 2006 Cellular senescence in aging primates. Science $\mathbf{3 1 1}$ 1257. (doi:10.1126/ science.1122446)

Hirota Y, Daikoku T, Tranguch S, Xie H, Bradshaw HB \& Dey SK 2010 Uterine-specific p53 deficiency confers premature uterine senescence and promotes preterm birth in mice. Journal of Clinical Investigation 120 803-815. (doi:10.1172/JCI40051)

Hirota Y, Cha J, Yoshie M, Daikoku T \& Dey SK 2011 Heightened uterine mammalian target of rapamycin complex 1 (mTORC1) signaling provokes preterm birth in mice. PNAS 108 18073-18078 (doi:10.1073/pnas.1108180108)

Holinka CF \& Finch CE 1977 Age-related changes in the decidual response of the C57BL/6J mouse uterus. Biology of Reproduction 16 385-393. (doi:10.1095/biolreprod16.3.385)

Huang L, Sauve R, Birkett N, Fergusson D \& van Walraven C 2008 Maternal age and risk of stillbirth: a systematic review. Canadian Medical Association Journal 178 165-172. (doi:10.1503/cmaj.070150)

Jackson MR, Mayhew TM \& Boyd PA 1992 Quantitative description of the elaboration and maturation of villi from 10 weeks of gestation to term. Placenta 13 357-370. (doi:10.1016/0143-4004(92)90060-7)

Jeyapalan JC, Ferreira M, Sedivy JM \& Herbig U 2007 Accumulation of senescent cells in mitotic tissue of aging primates. Mechanisms of Ageing and Development 128 36-44. (doi:10.1016/ j.mad.2006.11.008)

Kacerovsky M, Lenco J, Musilova I, Tambor V, Lamont R, Torloni MR \& Menon R (PREBIC Biomarker Working Group 2012-2013) 2014 Proteomic biomarkers for spontaneous preterm birth: a systematic review of the literature. Reproductive Sciences 21 283-295. (doi:10.1177/1933719113503415)

Kang C, Xu Q, Martin TD, Li MZ, Demaria M, Aron L, Lu T, Yankner BA, Campisi J \& Elledge SJ 2015 The DNA damage response induces inflammation and senescence by inhibiting autophagy of GATA4. Science 349 aa5612. (doi:10.1126/science.aaa5612)

Kasai H \& Nishimura S 1986 Hydroxylation of guanine in nucleosides and DNA at the C-8 position by heated glucose and oxygen radicalforming agents. Environmental Health Perspectives 67 111-116. (doi:10.1289/ehp.8667111)
Kasai H, Crain PF, Kuchino Y, Nishimura S, Ootsuyama A \& Tanooka H 1986 Formation of 8-hydroxyguanine moiety in cellular DNA by agents producing oxygen radicals and evidence for its repair. Carcinogenesis 7 1849-1851. (doi:10.1093/carcin/7.11.1849)

Kazzi GM, Gross TL, Sokol RJ \& Kazzi NJ 1983 Detection of intrauterine growth retardation: a new use for sonographic placental grading. American Journal of Obstetrics and Gynecology 145 733-737. (doi:10.1016/0002-9378(83)90582-3)

Keefe DL, Franco S, Liu L, Trimarchi J, Cao B, Weitzen S, Agarwal S \& Blasco MA 2005 Telomere length predicts embryo fragmentation after in vitro fertilization in women-toward a telomere theory of reproductive aging in women. American Journal of Obstetrics and Gynecology 192 1256-1261. (doi:10.1016/j.ajog.2005.01.036)

Keefe DL, Liu L \& Marquard K 2007 Telomeres and aging-related meiotic dysfunction in women. Cellular and Molecular Life Sciences 64 139-143. (doi:10.1007/s00018-006-6466-z)

Khan RN, Matharoo-Ball B \& Shaw RW 2010 Antioxidant enzyme expression, lipid peroxidation, and protein oxidation in human myometrium with parturition. Reproductive Sciences 17 78-84. (doi:10.1177/1933719109348027)

Kjaergaard N, Helmig RB, Schønheyder HC, Uldbjerg N, Hansen ES \& Madsen H 1999 Chorioamniotic membranes constitute a competent barrier to group b streptococcus in vitro. European Journal of Obstetrics, Gynecology, and Reproductive Biology 83 165-169. (doi:10.1016/ S0301-2115(99)00009-3)

Klungland A, Rosewell I, Hollenbach S, Larsen E, Daly G, Epe B, Seeberg E, Lindahl T \& Barnes DE 1999 Accumulation of premutagenic DNA lesions in mice defective in removal of oxidative base damage. PNAS 96 13300-13305. (doi:10.1073/pnas.96.23.13300)

König J, Huppertz B, Desoye G, Parolini O, Fröhlich JD, Weiss G, Dohr G, Sedlmayr P \& Lang I 2012 Amnion-derived mesenchymal stromal cells show angiogenic properties but resist differentiation into mature endothelial cells. Stem Cells and Development 21 1309-1320. (doi:10.1089/scd.2011.0223)

Konishi A, Shimizu S, Hirota J, Takao T, Fan Y, Matsuoka Y, Zhang L, Yoneda Y, Fujii Y, Skoultchi AI, et al. 2003 Involvement of histone H1.2 in apoptosis induced by DNA double-strand breaks. Cell 114 673-688. (doi:10.1016/S0092-8674(03)00719-0)

Kort DH, Gosselin J, Choi JM, Thornton MH, Cleary-Goldman J \& Sauer MV 2012 Pregnancy after age 50: defining risks for mother and child. American Journal of Perinatology 29 245-250. (doi:10.105 5/s-0031-1285101)

Kosanke G, Castellucci M, Kaufmann P \& Mironov VA 1993 Branching patterns of human placental villous trees: perspectives of topological analysis. Placenta 14 591-604. (doi:10.1016/S0143-4004(05)80212-7)

Koshimizu U, Taga T, Watanabe M, Saito M, Shirayoshi Y, Kishimoto T \& Nakatsuji N 1996 Functional requirement of gp130-mediated signaling for growth and survival of mouse primordial germ cells in vitro and derivation of embryonic germ (EG) cells. Development 122 1235-1242.

Kumar D, Springel E, Moore RM, Mercer BM, Philipson E, Mansour JM, Mesiano S, Schatz F, Lockwood CJ \& Moore JJ 2015 Progesterone inhibits in vitro fetal membrane weakening. American Journal of Obstetrics and Gynecology 213 520.e1-520.e9. (doi:10.1016/ j.ajog.2015.06.014)

Kusama K, Yoshie M, Tamura K, Nakayama T, Nishi H, Isaka K \& Tachikawa E 2014 The role of exchange protein directly activated by cyclic AMP 2-mediated calreticulin expression in the decidualization of human endometrial stromal cells. Endocrinology 155 240-248. (doi:10.1210/en.2013-1478)

Kyo S, Takakura M, Tanaka M, Kanaya T, Sagawa T, Kohama T, Ishikawa H, Nakano T, Shimoya K \& Inoue M 1997 Expression of telomerase activity in human chorion. Biochemical and Biophysical Research Communications 241 498-503. (doi:10.1006/bbrc.1997.7767)

Laberge RM, Sun Y, Orjalo AV, Patil CK, Freund A, Zhou L, Curran SC, Davalos AR, Wilson-Edell KA, Liu S, et al. 2015 MTOR regulates 
the pro-tumorigenic senescence-associated secretory phenotype by promoting IL1A translation. Nature Cell Biology 17 1049-1061. (doi:10.1038/ncb3195)

Laser J, Lee P \& Wei JJ 2010 Cellular senescence in usual type uterine leiomyoma. Fertility and Sterility 93 2020-2026. (doi:10.1016/ j.fertnstert.2008.12.116)

Lavranos TC, Mathis JM, Latham SE, Kalionis B, Shay JW \& Rodgers RJ 1999 Evidence for ovarian granulosa stem cells: telomerase activity and localization of the telomerase ribonucleic acid component in bovine ovarian follicles. Biology of Reproduction 61 358-366. (doi:10.1095/biolreprod61.2.358)

Lee HW, Blasco MA, Gottlieb GJ, Horner JW 2nd, Greider CW \& DePinho RA 1998 Essential role of mouse telomerase in highly proliferative organs. Nature 392 569-574. (doi:10.1038/33345)

Li W \& Challis JR 2005 Corticotropin-releasing hormone and urocortin induce secretion of matrix metalloproteinase-9 (MMP-9) without change in tissue inhibitors of MMP-1 by cultured cells from human placenta and fetal membranes. Journal of Clinical Endocrinology and Metabolism 90 6569-6574 (doi:10.1210/jc.2005-1445)

Liao Y, Jiang Y, He H, Ni H, Tu Z, Zhang S, Wang B, Lou J, Quan S \& Wang H 2015 NEDD8-mediated neddylation is required for human endometrial stromal proliferation and decidualization. Human Reproduction 30 1665-1676. (doi:10.1093/humrep/dev117)

Lin F, Ma XS, Wang ZB, Wang ZW, Luo YB, Huang L, Jiang ZZ, Hu MW, Schatten H \& Sun QY 2014 Different fates of oocytes with DNA double-strand breaks in vitro and in vivo. Cell Cycle 13 2674-2680. (doi:10.4161/15384101.2015.945375)

Liu L, Franco S, Spyropoulos B, Moens PB, Blasco MA \& Keefe DL 2004 Irregular telomeres impair meiotic synapsis and recombination in mice. PNAS 101 6496-6501. (doi:10.1073/pnas.0400755101)

Liu L, Bailey SM, Okuka M, Muñoz P, Li C, Zhou L, Wu C, Czerwiec E, Sandler L, Seyfang A, et al. 2007 Telomere lengthening early in development. Nature Cell Biology 9 1436-1441. (doi:10.1038/ncb1664)

Liu S, Uppal H, Demaria M, Desprez PY, Campisi J \& Kapahi P 2015 Simvastatin suppresses breast cancer cell proliferation induced by senescent cells. Scientific Reports 5 17895. (doi:10.1038/srep17895)

Mahadevaiah SK, Turner JM, Baudat F, Rogakou EP, de Boer P, Blanco-Rodríguez J, Jasin M, Keeney S, Bonner WM \& Burgoyne PS 2001 Recombinational DNA double-strand breaks in mice precede synapsis. Nature Genetics 27 271-276. (doi:10.1038/85830)

Many A \& Roberts JM 1997 Increased xanthine oxidase during labour-implications for oxidative stress. Placenta 18 725-726. (doi:10.1016/S0143-4004(97)90015-1)

Marcotte R, Lacelle C \& Wang E 2004 Senescent fibroblasts resist apoptosis by downregulating caspase-3. Mechanisms of Ageing and Development 125 777-783. (doi:10.1016/j.mad.2004.07.007)

Matsuda F, Inoue N, Manabe N \& Ohkura S 2012 Follicular growth and atresia in mammalian ovaries: regulation by survival and death of granulosa cells. Journal of Reproduction and Development 58 44-50. (doi:10.1262/jrd.2011-012)

Matsui Y, Zsebo K \& Hogan BL 1992 Derivation of pluripotential embryonic stem cells from murine primordial germ cells in culture. Cell 70 841-847. (doi:10.1016/0092-8674(92)90317-6)

Maurer RR \& Foote RH 1971 Maternal ageing and embryonic mortality in the rabbit. I. Repeated superovulation, embryo culture and transfer. Journal of Reproduction and Fertility 25 329-341. (doi:10.1530/ jrf.0.0250329)

McCance DR, Pettitt DJ, Hanson RL, Jacobsson LT, Knowler WC \& Bennett PH 1994 Birth weight and non-insulin dependent diabetes: thrifty genotype, thrifty phenotype, or surviving small baby genotype? British Medical Journal 308 942-945. (doi:10.1136/ bmj.308.6934.942)

McGee EA \& Hsueh AJ 2000 Initial and cyclic recruitment of ovarian follicles. Endocrine Reviews 21 200-214. (doi:10.1210/edrv.21.2.0394)

McKenna D, Tharmaratnam S, Mahsud S \& Dornan J 2005 Ultrasonic evidence of placental calcification at 36 weeks' gestation: Maternal

http://joe.endocrinology-journals.org

DOI: $10.1530 / J O E-16-0018$
๑ 2016 Society for Endocrinology Printed in Great Britain and fetal outcomes. Acta Obstetricia et Gynecologica Scandinavica 84 7-10. (doi:10.1111/j.0001-6349.2005.00563.x)

Meekins JW, Luckas MJ, Pijnenborg R \& McFadyen IR 1997 Histological study of decidual spiral arteries and the presence of maternal erythrocytes in the intervillous space during the first trimester of normal human pregnancy. Placenta 18 459-464. (doi:10.1016/ S0143-4004(97)80048-3)

Meng Y, Murtha AP \& Feng L 2016 Progesterone, inflammatory cytokine $(\mathrm{TNF}-\alpha)$, and oxidative stress (H2O2) regulate progesterone receptor membrane component 1 expression in fetal membrane cells. Reproductive Sciences [in press]. (doi:10.1177/1933719116630412)

Menon R, McIntyre JO, Matrisian LM \& Fortunato SJ 2006 Salivary proteinase activity: a potential biomarker for preterm premature rupture of the membranes. American Journal of Obstetrics and Gynecology 194 1609-1615. (doi:10.1016/j.ajog.2006.02.052)

Menon R, Arora CP, Hobel CJ \& Fortunato SJ 2008 Corticotrophinreleasing hormone in lipopolysaccharide-stimulated term fetal membranes and amniotic fluid from term and preterm birth in African Americans and Caucasians. Reproductive Sciences 15 477-483. (doi:10.1177/1933719108315300)

Menon R, Fortunato SJ, Milne GL, Brou L, Carnevale C, Sanchez SC, Hubbard L, Lappas M, Drobek CO \& Taylor RN 2011 a Amniotic fluid eicosanoids in preterm and term births: effects of risk factors for spontaneous preterm labor. Obstetrics and Gynecology 118 121-134. (doi:10.1097/aog.0b013e3182204eaa)

Menon R, Torloni MR, Voltolini C, Torricelli M, Merialdi M, Betrán AP, Widmer M, Allen T, Davydova I, Khodjaeva Z, et al. 2011 b Biomarkers of spontaneous preterm birth: an overview of the literature in the last four decades. Reproductive Sciences 18 1046-1070. (doi:10.1177/1933719111415548)

Menon R, Yu J, Basanta-Henry P, Brou L, Berga SL, Fortunato SJ \& Taylor RN 2012 Short fetal leukocyte telomere length and preterm prelabor rupture of the membranes. PLOS ONE 7 e31136. (doi:10.1371/journal.pone.0031136)

Menon R, Boldogh I, Urrabaz-Garza R, Polettini J, Syed TA, Saade GR, Papaconstantinou J \& Taylor RN 2013 Senescence of primary amniotic cells via oxidative DNA damage. PLoS ONE 8 e83416. (doi:10.1371/journal.pone.0083416)

Menon R, Boldogh I, Hawkins HK, Woodson M, Polettini J, Syed TA, Fortunato SJ, Saade GR, Papaconstantinou J \& Taylor RN 2014a Histological evidence of oxidative stress and premature senescence in preterm premature rupture of the human fetal membranes recapitulated in vitro. American Journal of Pathology 184 1740-1751. (doi:10.1016/j.ajpath.2014.02.011)

Menon R, Polettini J, Syed TA, Saade GR \& Boldogh I 2014b Expression of 8-oxoguanine glycosylase in human fetal membranes. American Journal of Reproductive Immunology 72 75-84. (doi:10.1111/aji.12220)

Menon R, Noda N, Bredeson S \& Polettini J 2015 Fetal membranes: potential source of preterm birth biomarkers. In General Methods in Biomarker Research and their Applications, edn 1, pp 483-529. Ed VR Preedy. London, UK: Springer Science Publisher. (doi:10.1007/978-94-007-7696-8_28)

Menon R, Behnia F, Polettini J, Saade GR, Campisi J \& Velarde M 2016 Placental membrane aging and HMGB1 signaling associated with human parturition. Aging 8 216-230. (doi:10.18632/aging.100891)

Mouton RE \& Venable ME 2000 Ceramide induces expression of the senescence histochemical marker, beta-galactosidase, in human fibroblasts. Mechanisms of Ageing and Development 113 169-181. (doi:10.1016/S0047-6374(99)00105-0)

Muñoz-Espín D, Cañamero M, Maraver A, Gómez-López G, Contreras J, Murillo-Cuesta S, Rodríguez-Baeza A, Varela-Nieto I, Ruberte J, Collado M, et al. 2013 Programmed cell senescence during mammalian embryonic development. Cell 155 1104-1118. (doi:10.1016/j.cell.2013.10.019)

Navot D, Bergh PA, Williams MA, Garrisi GJ, Guzman I, Sandler B \& Grunfeld L 1991 Poor oocyte quality rather than implantation 
failure as a cause of age-related decline in female fertility. Lancet $\mathbf{3 3 7}$ 1375-1377. (doi:10.1016/0140-6736(91)93060-M)

Noureddine H, Gary-Bobo G, Alifano M, Marcos E, Saker M, Vienney N, Amsellem V, Maitre B, Chaouat A, Chouaid C, et al. 2011 Pulmonary artery smooth muscle cell senescence is a pathogenic mechanism for pulmonary hypertension in chronic lung disease. Circulation Research 109 543-553. (doi:10.1161/CIRCRESAHA.111.241299)

Nybo Andersen AM, Wohlfahrt J, Christens P, Olsen J \& Melbye M 2000 Maternal age and fetal loss: population based register linkage study. British Medical Journal 320 1708-1712. (doi:10.1136/ bmj.320.7251.1708)

Ohta Y 1987 Age-related decline in deciduogenic ability of the rat uterus Biology of Reproduction 37 779-785. (doi:10.1095/biolreprod37.4.779)

Osmond C, Barker DJ, Winter PD, Fall CH \& Simmonds SJ 1993 Early growth and death from cardiovascular disease in women. British Medical Journal 307 1519-1524. (doi:10.1136/bmj.307.6918.1519)

Pandey V, Jaremko K, Moore RM, Mercer BM, Stetzer B, Kumar D, Fox JM, Mansour JM \& Moore JJ 2007 The force required to rupture fetal membranes paradoxically increases with acute in vitro repeated stretching. American Journal of Obstetrics and Gynecology 196165. e1-165.e7. (doi:10.1016/j.ajog.2006.10.861)

Parkening TA \& Soderwall AL 1973 Delayed embryonic development and implantation in senescent golden hamsters. Biology of Reproduction $\mathbf{8}$ 427-434.

Parkening TA \& Soderwall AL 1974 Delayed fertilisation in senescent golden hamsters. Nature 251 723-724. (doi:10.1038/251723a0)

Parkening TA \& Soderwall AL 1975 Delayed fertilization and preimplantation loss in senescent golden hamsters. Biology of Reproduction 12 618-631. (doi:10.1095/biolreprod12.5.618)

Patterson RM, Hayashi RH \& Cavazos D 1983 Ultrasonographically observed early placental maturation and perinatal outcome. American Journal of Obstetrics and Gynecology 147 773-777. (doi:10.1016/0002-9378(83)90035-2)

Pellestor F, Andréo B, Arnal F, Humeau C \& Demaille J 2003 Maternal aging and chromosomal abnormalities: new data drawn from in vitro unfertilized human oocytes. Human Genetics 112 195-203. (doi:10.1007/s00439-002-0852-x)

Perez GI \& Tilly JL 1997 Cumulus cells are required for the increased apoptotic potential in oocytes of aged mice. Human Reproduction 12 2781-2783. (doi:10.1093/humrep/12.12.2781)

Perez GI, Jurisicova A, Matikainen T, Moriyama T, Kim MR, Takai Y, Pru JK, Kolesnick RN \& Tilly JL 2005 A central role for ceramide in the age-related acceleration of apoptosis in the female germline. FASEB Journal 19 860-862. (doi:10.1096/fj.04-2903fje)

Pijnenborg R, Dixon G, Robertson WB \& Brosens I 1980 Trophoblastic invasion of human decidua from 8 to 18 weeks of pregnancy. Placenta 1 3-19. (doi:10.1016/S0143-4004(80)80012-9)

Pittman DL, Cobb J, Schimenti KJ, Wilson LA, Cooper DM, Brignull E, Handel MA \& Schimenti JC 1998 Meiotic prophase arrest with failure of chromosome synapsis in mice deficient for Dmc1, a germlinespecific RecA homolog. Molecular Cell 1 697-705. (doi:10.1016/ S1097-2765(00)80069-6)

Pitman RT, Wojdyla L \& Puri N 2013 Mechanism of DNA damage responses induced by exposure to an oligonucleotide homologous to the telomere overhang in melanoma. Oncotarget 4 761-771. (doi:10.18632/oncotarget)

Polettini J, Dutta EH, Behnia F, Saade GR, Torloni MR \& Menon R $2015 a$ Aging of intrauterine tissues in spontaneous preterm birth and preterm premature rupture of the membranes: a systematic review of the literature. Placenta 36 969-973. (doi:10.1016/j. placenta.2015.05.003)

Polettini J, Behnia F, Taylor BD, Saade GR, Taylor RN \& Menon R $2015 b$ Telomere fragment induced amnion cell senescence: a contributor to parturition? PLOS ONE 10 e0137188. (doi:10.1371/journal. pone.0137188)
Probin V, Wang Y, Bai A \& Zhou D 2006 Busulfan selectively induces cellular senescence but not apoptosis in WI38 fibroblasts via a p53-independent but extracellular signal-regulated kinase-p38 mitogen-activated protein kinase-dependent mechanism. Journal of Pharmacology and Experimental Therapeutics 319 551-560. (doi:10.1124/jpet.106.107771)

Puri N, Pitman RT, Mulnix RE, Erickson T, Iness AN, Vitali C, Zhao Y \& Salgia R 2014 Non-small cell lung cancer is susceptible to induction of DNA damage responses and inhibition of angiogenesis by telomere overhang oligonucleotides. Cancer Letters 343 14-23. (doi:10.1016/ j.canlet.2013.09.010)

Rahima A \& Bruce NW 1987 Fetal and placental growth in young, primiparous and old, multiparous rats. Experimental Gerontology 22 257-261. (doi:10.1016/0531-5565(87)90004-0)

Rajagopalan S \& Long EO 1999 A human histocompatibility leukocyte antigen (HLA)-G-specific receptor expressed on all natural killer cells. Journal of Experimental Medicine 189 1093-1100. (doi:10.1084/ jem.189.7.1093)

Rajagopalan S \& Long EO 2012 Cellular senescence induced by CD158d reprograms natural killer cells to promote vascular remodeling. PNAS 109 20596-20601. (doi:10.1073/pnas.1208248109)

Rajagopalan S, Bryceson YT, Kuppusamy SP, Geraghty DE, van der Meer A, Joosten I \& Long EO 2006 Activation of NK cells by an endocytosed receptor for soluble HLA-G. PLoS Biology 4 e9. (doi:10.1371/journal.pbio.0040009)

Rankin AM, Sarkar S \& Faller DV 2012 Mechanism of T-oligo-induced cell cycle arrest in Mia-PaCa pancreatic cancer cells. Journal of Cellular Physiology 227 2586-2594. (doi:10.1002/jcp.22997)

Ressler S, Bartkova J, Niederegger H, Bartek J, Scharffetter-Kochanek K, Jansen-Dürr P \& Wlaschek M 2006 p16INK4A is a robust in vivo biomarker of cellular aging in human skin. Aging Cell 5 379-389. (doi:10.1111/j.1474-9726.2006.00231.x)

Richardson SJ, Senikas V \& Nelson JF 1987 Follicular depletion during the menopausal transition: evidence for accelerated loss and ultimate exhaustion. Journal of Clinical Endocrinology and Metabolism 65 1231-1237. (doi:10.1210/jcem-65-6-1231)

Romero R, Friel LA, Velez Edwards DR, Kusanovic JP, Hassan SS, Mazaki-Tovi S, Vaisbuch E, Kim CJ, Erez O, Chaiworapongsa T, et al. $2010 a$ A genetic association study of maternal and fetal candidate genes that predispose to preterm prelabor rupture of membranes (PROM). American Journal of Obstetrics and Gynecology 203361. (doi:10.1016/j.ajog.2010.05.026)

Romero R, Velez Edwards DR, Kusanovic JP, Hassan SS, Mazaki-Tovi S, Vaisbuch E, Kim CJ, Chaiworapongsa T, Pearce BD, Friel LA, et al. $2010 \mathrm{~b}$ Identification of fetal and maternal single nucleotide polymorphisms in candidate genes that predispose to spontaneous preterm labor with intact membranes. American Journal of Obstetrics and Gynecology 202 431-434. (doi:10.1016/j.ajog.2010.03.026)

Romeu A, Muasher SJ, Acosta AA, Veeck LL, Diaz J, Jones GS, Jones HW Jr \& Rosenwaks Z 1987 Results of in vitro fertilization attempts in women 40 years of age and older: the Norfolk experience. Fertily and Sterility 47 130-136. (doi:10.1016/S0015-0282(16)49948-6)

Santoro N, Brown JR, Adel T \& Skurnick JH 1996 Characterization of reproductive hormonal dynamics in the perimenopause. Journal of Clinical Endocrinology \& Metabolism 81 1495-1501. (doi:10.1210/ jcem.81.4.8636357)

Sarkar S \& Faller DV 2011 T-oligos inhibit growth and induce apoptosis in human ovarian cancer cells. Oligonucleotides 21 47-53. (doi:10.1089/oli.2010.0259)

Sauer MV, Paulson RJ \& Lobo RA 1992 Reversing the natural decline in human fertility. An extended clinical trial of oocyte donation to women of advanced reproductive age. JAMA 268 1275-1279. (doi:10.1001/jama.1992.03490100073030)

Sedelnikova OA, Horikawa I, Zimonjic DB, Popescu NC, Bonner WM \& Barrett JC 2004 Senescing human cells and ageing mice accumulate http://joe.endocrinology-journals.org

DOI: $10.1530 / \mathrm{JOE}-16-0018$
() 2016 Society for Endocrinology Printed in Great Britain 
DNA lesions with unrepairable double-strand breaks. Nature Cell Biology 6 168-170. (doi:10.1038/ncb1095)

Serhal PF \& Craft IL 1989 Oocyte donation in 61 patients. Lancet 1 1185-1187. (doi:10.1016/S0140-6736(89)92762-1)

Shapiro M \& Talbert GB 1974 The effect of maternal age on decidualization in the mouse. Journal of Gerontology 29 145-148. (doi:10.1093/geronj/29.2.145)

Simmen RC, Heard ME, Simmen AM, Montales MT, Marji M, Scanlon S \& Pabona JM 2015 The Krüppel-like factors in female reproductive system pathologies. Journal of Molecular Endocrinology 54 R89-R101. (doi:10.1530/jme-14-0310)

Simsek-Duran F, Li F, Ford W, Swanson RJ, Jones HW Jr \& Castora FJ 2013 Age-associated metabolic and morphologic changes in mitochondria of individual mouse and hamster oocytes. PLOS ONE 8 e64955. (doi:10.1371/journal.pone.0064955)

Smith GC, Cordeaux Y, White IR, Pasupathy D, Missfelder-Lobos H, Pell JP, Charnock-Jones DS \& Fleming M 2008 The effect of delaying childbirth on primary cesarean section rates. PLoS Medicine 5 e144. (doi:10.1371/journal.pmed.0050144)

Soleimani R, Heytens E, Darzynkiewicz Z \& Oktay K 2011 Mechanisms of chemotherapy-induced human ovarian aging: double strand DNA breaks and microvascular compromise. Aging 3 782-793. (doi:10.18632/aging.100363)

Sousa-Victor P, Gutarra S, García-Prat L, Rodriguez-Ubreva J, Ortet L, Ruiz-Bonilla V, Jardí M, Ballestar E, González S, Serrano AL, et al. 2014 Geriatric muscle stem cells switch reversible quiescence into senescence. Nature 506 316-321. (doi:10.1038/nature13013)

Spallarossa P, Altieri P, Aloi C, Garibaldi S, Barisione C, Ghigliotti G, Fugazza G, Barsotti A \& Brunelli C 2009 Doxorubicin induces senescence or apoptosis in rat neonatal cardiomyocytes by regulating the expression levels of the telomere binding factors 1 and 2. American Journal of Physiology: Heart and Circulatory Physiology 297 H2169-H2181. (doi:10.1152/ ajpheart.00068.2009)

Steuerwald N, Cohen J, Herrera RJ, Sandalinas M, Brenner CA 2001 Association between spindle assembly checkpoint expression and maternal age in human oocytes. Molecular Human Reproduction 7 49-55. (doi:10.1093/molehr/7.1.49)

Storer M, Mas A, Robert-Moreno A, Pecoraro M, Ortells MC, Di Giacomo V, Yosef R, Pilpel N, Krizhanovsky V, Sharpe J, et al. 2013 Senescence is a developmental mechanism that contributes to embryonic growth and patterning. Cell 155 1119-1130. (doi:10.1016/j.cell.2013.10.041)

Strohl A, Kumar D, Novince R, Shaniuk P, Smith J, Bryant K, Moore RM, Novak J, Stetzer B, Mercer BM, et al. 2010 Decreased adherence and spontaneous separation of fetal membrane layers-amnion and choriodecidua - a possible part of the normal weakening process. Placenta 31 18-24. (doi:10.1016/ j.placenta.2009.10.012)

Templeton A, Morris JK \& Parslow W 1996 Factors that affect outcome of in-vitro fertilisation treatment. Lancet 348 1402-1406. (doi:10.1016/ S0140-6736(96)05291-9)

Tindall V \& Scott J 1965 Placental calcification a study of 3,025 singleton and multiple pregnancies. Journal of Obstetrics and Gynaecology of the British Commonwealth 72 356-373. (doi:10.1111/j.1471-0528.1965.tb01470.x)

Titus S, Li F, Stobezki R, Akula K, Unsal E, Jeong K, Dickler M, Robson M, Moy F, Goswami S, et al. 2013 Impairment of BRCA1-related DNA double-strand break repair leads to ovarian aging in mice and humans. Science Translational Medicine 5 172ra21. (doi:10.1126/ scitranslmed.3004925)

Tureck RW \& Strauss JF 3rd 1982 Progesterone synthesis by luteinized human granulosa cells in culture: the role of de novo sterol synthesis and lipoprotein-carried sterol. Journal of Clinical Endocrinology and Metabolism 54 367-373. (doi:10.1210/jcem-54-2-367)
Valdez R, Athens MA, Thompson GH, Bradshaw BS \& Stern MP 1994 Birthweight and adult health outcomes in a biethnic population in the USA. Diabetologia 37 624-631. (doi:10.1007/ BF00403383)

Velarde MC, Flynn JM, Day NU, Melov S \& Campisi J 2012 Mitochondrial oxidative stress caused by Sod 2 deficiency promotes cellular senescence and aging phenotypes in the skin. Aging 4 3-12. (doi:10.18632/aging.100423)

Velarde MC, Demaria M, Melov S \& Campisi J 2015 Pleiotropic age-dependent effects of mitochondrial dysfunction on epidermal stem cells. PNAS 112 10407-10412. (doi:10.1073/ pnas.1505675112)

Venable ME, Lee JY, Smyth MJ, Bielawska A \& Obeid LM 1995 Role of ceramide in cellular senescence. Journal of Biological Chemistry 270 30701-30708. (doi:10.1074/jbc.270.51.30701)

Vorherr H 1975 Placental insufficiency in relation to postterm pregnancy and fetal postmaturity. Evaluation of fetoplacental function; management of the postterm gravida. American Journal of Obstetrics and Gynecology 123 67-103. (doi:10.1016/00029378(75)90951-5)

Vosmar M, Jongsma H \& van Dongen P 1989 The value of ultrasonic placental grading: no correlation with intrauterine growth retardation or with maternal smoking. Journal of Perinatal Medicine 17 137-143. (doi:10.1515/jpme.1989.17.2.137)

Voutilainen R, Tapanainen J, Chung BC, Matteson KJ \& Miller WL 1986 Hormonal regulation of P450scc (20,22-desmolase) and P450c17 (17 alpha-hydroxylase/17,20-lyase) in cultured human granulosa cells. Journal of Clinical Endocrinology and Metabolism 63 202-207. (doi:10.1210/jcem-63-1-202)

Wallace WH \& Kelsey TW 2010 Human ovarian reserve from conception to the menopause. PLOS ONE 5 e8772. (doi:10.1371/journal. pone.0008772)

Wang H, Parry S, Macones G, Sammel MD, Kuivaniemi H, Tromp G, Argyropoulos G, Halder I, Shriver MD, Romero R, et al. 2006 A functional SNP in the promoter of the SERPINH1 gene increases risk of preterm premature rupture of membranes in African Americans. PNAS 103 13463-13467. (doi:10.1073/ pnas.0603676103)

Welsh M, Sharpe RM, Walker M, Smith LB \& Saunders PT 2009 New insights into the role of androgens in wolffian duct stabilization in male and female rodents. Endocrinology 150 2472-2480. (doi:10.1210/ en.2008-0529)

White YA, Woods DC, Takai Y, Ishihara O, Seki H \& Tilly JL 2012 Oocyte formation by mitotically active germ cells purified from ovaries of reproductive-age women. Nature Medicine 18 413-421. (doi:10.1038/nm.2669)

Wiley CD, Velarde MC, Lecot P, Liu S, Sarnoski EA, Freund A, Shirakawa K, Lim HW, Davis SS, Ramanathan A, et al. 2016 Mitochondrial dysfunction induces senescence with a distinct secretory phenotype. Cell Metabolism 23 303-314. (doi:10.1016/ j.cmet.2015.11.011)

Williams GC 1957 Pleiotropy, natural selection, and the evolution of senescence. Evolution 11 398-411. (doi:10.2307/2406060)

Witschi E 1948 Migration of germ cells of human embryos from the yolk sac to the primitive gonadal folds. Contributions to Embryology: Carnegie Institution of Washington 32 67-80.

Wright WE, Piatyszek MA, Rainey WE, Byrd W \& Shay JW 1996 Telomerase activity in human germline and embryonic tissues and cells. Developmental Genetics 18 173-179. (doi:10.1002/(sici)15206408(1996)18:2<173::aid-dvg10>3.0.co;2-3)

Wu J, Dong F, Wang RA, Wang J, Zhao J, Yang M, Gong W, Cui R \& Dong L 2013 Central role of cellular senescence in TSLP-induced airway remodeling in asthma. PLOS ONE 8 e77795. (doi:10.1371/ journal.pone.0077795)

Xu M, Tchkonia T, Ding H, Ogrodnik M, Lubbers ER, Pirtskhalava T, White TA, Johnson KO, Stout MB, Mezera V, et al. 2015 JAK inhibition alleviates the

Published by Bioscientifica Ltd. 
cellular senescence-associated secretory phenotype and frailty in old age. PNAS 112 E6301-E6310. (doi:10.1073/pnas.1515386112)

Yaar M, Eller MS, Panova I, Kubera J, Wee LH, Cowan KH \& Gilchrest BA 2007 Telomeric DNA induces apoptosis and senescence of human breast carcinoma cells. Breast Cancer Research 9 R13. (doi:10.1186/bcr1646)

Yamagata Y, Nakamura Y, Umayahara K, Harada A, Takayama H, Sugino N \& Kato H 2002 Changes in telomerase activity in experimentally induced atretic follicles of immature rats. Endocrine Journal 49 589-595. (doi:10.1507/endocri.49.589)
Yuan W \& Giudice LC 1997 Programmed cell death in human ovary is a function of follicle and corpus luteum status. Journal of Clinical Endocrinology and Metabolism 82 3148-3155. (doi:10.1210/jcem.82.9.4191)

Zhang H, Panula S, Petropoulos S, Edsgärd D, Busayavalasa K, Liu L, Li X, Risal S, Shen Y, Shao J, et al. 2015 Adult human and mouse ovaries lack DDX4-expressing functional oogonial stem cells. Nature Medicine 21 1116-1118. (doi:10.1038/ $\mathrm{nm} .3775)$

Received in final form 4 June 2016

Accepted 17 June 2016

Accepted Preprint published online 17 June 2016
Published by Bioscientifica Ltd. 